\title{
Influence of Soxhlet-extractable bitumen and oil on porosity in thermally
}

\section{maturing organic-rich shales}

\author{
Lin Wei $^{1}{ }^{*}$, Maria Mastalerz ${ }^{2}$, Arndt Schimmelmann ${ }^{1}$, Yanyan Chen ${ }^{1}$ \\ ${ }^{1}$ Department of Geological Sciences, Indiana University, Bloomington, IN 47405-1405, \\ $U S A$ \\ ${ }^{2}$ Indiana Geological Survey, Indiana University, Bloomington, IN 47405-2208, USA \\ (*correspondence: linwei@indiana.edu)
}

(C) 2014. This manuscript version is made available under the Elsevier user license http://www.elsevier.com/open-access/userlicense/1.0/ 


\section{Abstract}

Porosity in shales is important for storage of shale gas in reservoirs. As organic-rich shale thermally matures and enters the oil window, generated bitumen and oil can fill pore spaces, block pore connectivity, and reduce porosity. Low-pressure $\mathrm{N}_{2}$ and $\mathrm{CO}_{2}$ adsorption techniques were used to quantify mesoporosity (pore size 2-50 nm, accessible to $\mathrm{N}_{2}$ and $\mathrm{CO}_{2}$ ) and microporosity (pore size $<2 \mathrm{~nm}$, accessible to $\mathrm{CO}_{2}$ only) in New Albany Shale samples of Devonian and Mississippian age from Indiana and Illinois ranging from marginally mature (vitrinite reflectance $\left.\mathrm{R}_{\mathrm{o}}=0.55 \%\right)$ to post-mature $\left(\mathrm{R}_{0}=1.41 \%\right)$. After measuring their original porosity, the shale samples were Soxhlet-extracted in refluxing dichloromethane (DCM, boiling temperature $39.6{ }^{\circ} \mathrm{C}$ ) to remove soluble oil/bitumen, vacuum-dried, and then re-measured for meso and microporosities. Subsequently, the same samples were Soxhlet-extracted in toluene (boiling temperature $111^{\circ} \mathrm{C}$, with enhanced solubility of oil/bitumen), vacuum-dried, and again characterized porosimetrically.

The maturation sequence of the original, non-extracted shales expresses a higher mesoporosity in lower maturity samples (vitrinite reflectance $\mathrm{R}_{\mathrm{o}} 0.55 \%$, and $0.65 \%$ ), and an intermittent decrease in mesoporosity in samples of post-mature stage $\left(R_{o}\right.$ $1.15 \%)$ in two size fractions (4-mesh and 60-mesh). The intermittent decrease in mesoporosity is consistent with partial filling of pore spaces with bitumen and oil secondary cracking reclaims some of the lost open pore space from liquid phases. Organic matter $(\mathrm{OM})$ transformation is thus a pivotal cause for the observed evolution of mesoporosity in original, non-extracted shales. Micropore volumes 
display a varying trend throughout thermal maturation, and are significantly by total organic carbon content. Compared to 4-mesh sample fractions, a reduction in grain size of 60-mesh fractions for gas adsorption porosimetry prominently enhances mesopore volumes, whereas the effects on micropore volumes are variable. These findings may be associated with the fact that for smaller particles it is easier to attain equilibrium during gas adsorption porosimetry.

Solvent extraction of soluble bitumen and oil from the shale samples generally opens additional pore space for $\mathrm{N}_{2}$ and $\mathrm{CO}_{2}$ adsorption, although the specific effects on mesoporosity and microporosity depend on maturity, total organic carbon (TOC) content, type of solvent, and grain size of the Soxhlet-extracted shales. The mesopore volume increases more in extracted samples with higher maturity, whereas the strongest gain in micropore volume is observed at elevated TOC content and highest maturity. the evolution of porosity along maturation, as well as the effect of partial oil/bitumen filling and blocking of pores. This study also employs FTIR analyses of DCM and toluene Soxhlet extracts to differentiate low-temperature DCM-extractable, mostly aliphatic OM from higher-temperature toluene-soluble OM containing condensed cross-linked polyaromatic structures.

Keywords: shale, porosity, maturity, adsorption, extraction, KBr-FTIR

\section{Introduction}


Porosity plays a significant role in evaluating shale reservoir quality and the hydrocarbon potential (Hunt, 1995; Ertas et al., 2006; Loucks et al., 2009; Curtis et al., 2012; Jarvie, 2012; Romero-Sarmiento et al., 2013). Gas adsorption capacity in shales hinges on the volume of pores (Chalmers and Bustin, 2007; Bustin et al., 2008; Ross and Bustin, 2009; Curtis et al., 2011a), whereas pore size distribution and pore connectivity influence shale permeability (Bustin et al., 2008; Ross and Bustin, 2009; Clarkson et al., 2013). Knowledge of porosity characteristics, gas adsorption volumes, and shale heterogeneity aids in the prediction of shale gas contents of reservoirs, reduces the shale gas exploration risk, and mitigates production uncertainties (Pollastro et al., 2007; Bustin et al., 2008; Ross and Bustin, 2009).

In contrast to conventional reservoirs, shales have complex porosity systems featuring interparticle and intraparticle pore components (Loucks et al., 2009, 2012). Significant contributions of intraparticle porosity derive from macerals in organic-rich shales (Chalmers and Bustin, 2008; Jarvie et al., 2011). The existence of abundant nanopores in organic-rich shales has been suggested by various techniques, including low-pressure gas adsorption (e.g., Ross and Bustin, 2009; Clarkson et al., 2013; Mastalerz et al., 2013) and low-angle scattering (e.g., Melnichenko et al., 2009; Mastalerz et al., 2012; Clarkson et al., 2013). Argon ion-milling and subsequent scanning electron microscopy (SEM) of Barnett Shale imaged the presence of nanopores in close association with organic matter (OM) (Loucks et al., 2009; Slatt O’Brien, 2011). Nanopores are generated during burial and maturation of OM (Jarvie al., 2007; Bernard et al., 2012) and are generally isolated in organic flakes (Jarvie et 
2007). Field emission scanning electron microscopy (FE-SEM) and transmission electron microscopy (TEM) image analysis were able to provide an appreciation of complexity of pore networks in Marcellus Shale (Chalmers et al., 2012) and that macropores and mesopores are interconnected (Curtis et al., 2011a). Furthermore, recent petrologic evidence suggests that the thermochemical conversion of kerogen to oil, bitumen, and gas creates an OM-hosted nanopore network (Loucks et al., 2009; Modica and Lapierre, 2012). It is now generally accepted that the pore network in the organic component of OM-rich shales plays an important role for the storage of hydrocarbons (Loucks et al., 2009; Wang and Reed, 2009; Passey et al., 2010; Curtis al., 2011b; Mastalerz et al., 2013).

In spite of recent progress, the development of porosity with increasing maturity of organic-rich shales remains controversial. Original immature kerogen owes its internal porosity to the structure of partially preserved biological tissues. Thermal cracking and the loss of hydrocarbons along maturation may add new pores or enlarge pre-existing ones, but research has failed to provide unambiguous and quantitative measures. For example, Milliken et al. (2013) demonstrated that variations in total organic carbon (TOC) content exert stronger control on organic-hosted pore systems than thermal maturity between vitrinite reflectance $\left(\mathrm{R}_{\mathrm{o}}\right)$ values 1.0 and $2.1 \%$. SEM visualization of comparatively sized and shaped pores in low and high-maturity Jurassic Kimmeridge Clay Formation shales from the North Sea prompted Fishman et al. (2012) to claim that pores were not related to OM transformation. In contrast, Mastalerz et al. (2013) investigated porosity in a suite of Devonian and Mississippian 
New Albany Shale samples collected from core material archived at the Indiana Geological Survey and the Illinois State Geological Survey with different maturities and concluded that OM transformation and migration are major causes for observed differences in porosity.

Maturation of kerogen generates liquid hydrocarbons that can occupy and/or obstruct, and thus mask open pore space. An improved understanding of the pore hydrocarbon filling in shales constrains the inventory of pre-hydrocarbon and the formation of new evolving hydrocarbon related porosity. For example, Bernard et al. (2012) documented the chemical evolution from immature $\left(\mathrm{T}_{\max } 420{ }^{\circ} \mathrm{C}\right)$ to post-mature $\left(\mathrm{T}_{\max }>500{ }^{\circ} \mathrm{C}\right)$ Mississippian Barnett Shale (Fort Worth Basin, Texas, USA) and suggested that nanoporous pyrobitumen was formed as a result of secondary cracking at the post-mature stage. At an early mature stage, the removal of solvent-extractable hydrocarbons can modify OM porosity, as recently documented on high-volatile bituminous coals (Furmann et al., 2013). Similarly, other studies strongly suggested that hydrocarbon generation, cracking, and the formation of solid bitumen can influence the porosity of shales (Jarvie et al., 2007; Loucks et al., 2009; Mastalerz et al., 2013). Weatherford Laboratories routinely conduct porosity measurements following Gas Research Institute (GRI) procedures for core analyses and use the standard Dean-Stark toluene extraction process prior to porosimetry (Lasswell, 2011), but few published data have compared pre- and post-extraction porosity with maturity (Valenza et al., 2013). Further evidence is needed to clarify the impact of generated hydrocarbon products on porosity at different stages of maturation. 
In a recent study of porosity in the New Albany Shale across a range of maturity, Mastalerz et al. (2013) suggested that hydrocarbon-related phenomena influenced total porosity and modified pore size distributions in response to increasing maturity. The present study is a continuation of that work, aiming to elucidate the influence of solvent-extractable OM on mesopores and micropores in shales.

\section{Materials and Methods}

\subsection{Low-pressure gas adsorption measurements}

This study utilized four samples (MM4, NA2, IL-5 and IL-1) of the New Albany Shale from Indiana and Illinois with maturities corresponding to $\mathrm{R}_{\mathrm{o}}$ values of 0.55 , $0.65,1.15$, and $1.41 \%$ (Table 1 ), thus covering a range from marginally mature (MM4) to post-mature (IL-1). The OM content expressed as TOC concentration ranges from 4.3 to $13.0 \mathrm{wt}$. \% (Table 1$)$. The porosities of the original, unextracted 4 -mesh $(<4.76$ $\mathrm{mm}$ diameter) samples have been characterized in our previous study (Mastalerz et al., 2013).

This study used 2-g aliquots of two different size fractions from each shale that were individually folded into filter paper like 'tea bags' in preparation for Soxhlet-extractions with organic solvents. The $<4.76 \mathrm{~mm}$ grain size samples are referred to as 4-mesh fractions, whereas the $<0.250 \mathrm{~mm}$ size grain size samples are called 60-mesh fractions. We use subscript numbers after sample acronyms to distinguish between 4 and 60-mesh fractions and additionally mark original samples before extraction (e.g., MM4 4 orig and MM4 $4_{60 \text { orig }}$ ). The TOC values of two shale 
fractions_are comparable. Each sample was first characterized porosimetrically before being Soxhlet-extracted with refluxing dichloromethane (DCM, $\left.\mathrm{CH}_{2} \mathrm{Cl}_{2}\right)$ at $39.6{ }^{\circ} \mathrm{C}$ for 72 hours. After vacuum-drying and non-destructive gas adsorption porosimetry measurements, a second Soxhlet-extraction of the same samples used refluxing toluene $\left(\mathrm{C}_{7} \mathrm{H}_{8}\right)$ at $111{ }^{\circ} \mathrm{C}$ for 96 hours, followed by vacuum-drying for two days and repeated porosimetry. DCM's lower boiling point limits the solubility of larger hydrocarbon molecules and bitumen, while the higher boiling point and aromatic character of toluene enhance dissolution of bitumen and moderately cross-linked bituminous OM. Solvent-extracted samples are characterized by additional subscript letters D for dichloromethane and T for toluene (e.g., MM4 $4_{4 \mathrm{D}}$ and $\mathrm{MM} 4_{60 \mathrm{~T}}$, respectively). Subscript $\mathrm{T}$ implies that the sample had been extracted sequentially with DCM and toluene. The toxicity and flammability of both solvents mandate the use of chemical fume hoods.

Low-pressure gas adsorption measurements with nitrogen $\left(\mathrm{N}_{2}\right)$ and carbon dioxide $\left(\mathrm{CO}_{2}\right)$ were conducted on a Micromeritics ASAP-2020 gas adsorption porosimeter. Shale sample aliquots were analyzed with $\mathrm{N}_{2}$ to obtain information about mesopores (2-50 $\mathrm{nm}$ in diameter), whereas $\mathrm{CO}_{2}$ was used to characterize micropores $\left(<2 \mathrm{~nm}\right.$ in diameter) that are more accessible for $\mathrm{CO}_{2}$ than for $\mathrm{N}_{2}$. The classification of pore sizes follows the system of the International Union of Pure and Applied Chemistry (Orr, 1977). Samples were automatically degassed at $\sim 110^{\circ} \mathrm{C}$ under vacuum for about 14 hours to remove adsorbed moisture and volatile matter prior to adsorption analyses with either $\mathrm{N}_{2}$ or $\mathrm{CO}_{2}$. Nitrogen gas adsorption was quantified 
after exposure to $\mathrm{N}_{2}$ at a pressure up to $97.3 \mathrm{kPa}(730 \mathrm{~mm} \mathrm{Hg})$ at the temperature of liquid nitrogen $-196{ }^{\circ} \mathrm{C}(\sim 77 \mathrm{~K}) . \mathrm{CO}_{2}$ adsorption occurred at a pressure of up to 104.5 $\mathrm{kPa}(784 \mathrm{~mm} \mathrm{Hg})$ at $0{ }^{\circ} \mathrm{C}(\sim 273 \mathrm{~K})$. The equilibration interval (i.e., the time during which the pressure must remain stable within a narrow range) was 30 seconds and the pressure tolerance was set at $\pm 0.666 \mathrm{kPa}$ (i.e., $\pm 5 \mathrm{~mm} \mathrm{Hg}$ ). Low-pressure adsorption isotherms were used to calculate surface areas, pore volumes, and pore distributions based on multiple adsorption theories, i.e., Langmuir, Brunauer-Emmett-Teller (BET), Barrett-Joyner-Halenda (BJH), Dubinin-Radushkevich (D-R), and Dubinin-Astakhov (D-A), among others. Mesopore size distribution was determined by the BJH method, whereas micropore size distribution was determined by the Density Functional Theory (DFT) method (Webb and Orr, 1997). A detailed description of theories and techniques can be found in Gregg and Sing (1982).

\subsection{Potassium bromide ( $\mathrm{KBr})$ —FTIR analysis}

A few drops of extracted bitumen and oil from DCM and toluene Soxhlet extractions were diluted with the respective pure solvents DCM or toluene, followed by mixing with $300 \mathrm{mg}$ of $\mathrm{KBr}$ in an agate mortar. Pure DCM and toluene were mixed separately with $\mathrm{KBr}$ for comparative FTIR measurements. The preparation of $\mathrm{KBr}$ pellets relied on our standardized procedure (i.e., grinding time, pressure, and pellet weight) to enhance reproducibility (Chen et al., 2012). Pellets for KBr-FTIR characterization were analyzed on a Nicolet 6700 spectrometer equipped with a DTGS detector, collecting 400 scans per sample at a resolution of $4 \mathrm{~cm}^{-1}$. The FTIR signals of oil and bitumen in spectra of solvent-containing extracts were separated 
from those of the solvents via subtraction of the spectra of pure solvents.

\section{Results}

\subsection{Mesopores}

Significant differences in the quantities of adsorbed $\mathrm{N}_{2}$ among the studied samples translate into differences in surface areas and mesopore volumes.

Low-pressure $\mathrm{N}_{2}$ adsorption isotherms for original, non-extracted 4-mesh fractions indicate that early mature sample NA2 ${ }_{4 \text { orig }}\left(\mathrm{R}_{\mathrm{o}} 0.65 \%\right)$ and post-mature sample IL-1 $1_{\text {4orig }}\left(\mathrm{R}_{\mathrm{o}} 1.41 \%\right)$ adsorb more $\mathrm{N}_{2}$ than the other two samples (Fig. 1A), and therefore NA2 ${ }_{4 \text { orig }}$ and $\mathrm{IL}-1_{4 \text { orig }}$ have relatively larger BET surface areas (Fig. 1A). The equivalent relationship holds for $\mathrm{BJH}$ mesopore volumes (Fig. 2B) where marginally mature sample $M M 4_{4 \text { orig }}\left(R_{o} 0.55 \%\right)$ and late mature sample IL-5 $5_{\text {orig }}\left(R_{o}\right.$ $1.15 \%)$ express lowest mesopore volumes.

Soxhlet extraction of the same 4-mesh fractions with DCM did not cause noticeable changes in the quantities of adsorbed $\mathrm{N}_{2}$ for marginally mature sample $\mathrm{MM}_{4 \mathrm{D}}$ (Fig. 3A) or late mature sample IL-54D (Fig. 3C), but resulted in large increases in adsorbed $\mathrm{N}_{2}$ in early mature sample NA2 ${ }_{4 D}$ (Fig. 3B) and post-mature sample IL-1 $1_{4 \mathrm{D}}$ (Fig. 3D). These observations relate to $82 \%$ and $26 \%$ increases in BET surface areas and mesopore volumes, respectively, in early mature NA2 $2_{4 \mathrm{D}}$, as well as respective $161 \%$ and $22 \%$ increases in post-mature $\mathrm{IL}-1_{4 \mathrm{D}}($ Table 2$)$.

Subsequent Soxhlet extraction with toluene at the elevated temperature of $111{ }^{\circ} \mathrm{C}$ (i) further increased the quantity of adsorbed $\mathrm{N}_{2}$ in all 4-mesh samples (Fig. 3A-D), (ii) increased the surface areas in early mature NA2 ${ }_{4 \mathrm{~T}}$ and post-mature IL- $1_{4 \mathrm{~T}}$ (Fig. $2 \mathrm{~A}$ ), 
and (iii) greatly increased the mesopore volume in sample $\mathrm{NA} 2_{4 \mathrm{~T}}$ (Fig. 2B). Similar to DCM extraction, Soxhlet extraction with toluene did not result in notable increases in surface areas or mesopore volumes for marginally mature sample MM4 $4_{4 \mathrm{~T}}$. However, toluene extraction of sample IL- $5_{4 \mathrm{~T}}$ caused an $820 \%$ increase in mesopore surface area and a $223 \%$ increase in mesopore volume, which are the largest increases among all four samples (Table 2).

In contrast to the original, non-extracted 4-mesh fractions, low-pressure $\mathrm{N}_{2}$ adsorption isotherms of $\mathrm{MM} 4_{60 \text { orig }}$ and NA2 $60_{\text {orig }}$ indicate increased adsorption of $\mathrm{N}_{2}$ relative to the two higher-maturity samples $\mathrm{IL}-5_{60 \text { orig }}$ and $\mathrm{IL}-1_{60 \text { orig }}$ (Fig. 1D). Consequently, the largest BET surface area in non-extracted 60-mesh samples occurs in marginally mature sample MM460orig and the smallest BET surface area is found in post-mature sample IL-160rig $($ Fig. $4 \mathrm{~A})$.

In general, DCM extraction of the 60-mesh fraction causes little change in the quantity of adsorbed $\mathrm{N}_{2}$ (Fig. 3E-H) except in case of the late mature sample IL-560D (Fig. 3G). In contrast, extraction with toluene increases the volumes of adsorbed $\mathrm{N}_{2}$ for all samples, with the smallest increase observed in the marginally mature sample $\mathrm{MM}_{60 \mathrm{~T}}$ (Fig. 3E). Similar to the 4-mesh fraction, extraction with toluene increases the surface area in all 60-mesh samples, with the largest increase in late mature sample IL-560T and post mature sample IL-1 ${ }_{60 \mathrm{~T}}$ (Fig. 4A). Toluene extraction strongly increases measured surface areas. However, unlike the 4-mesh fractions, extractions of the 60-mesh fractions with either solvent fail to increase mesopore volumes (Fig. 4B). Mesopore surface areas increase with maturity after toluene extractions of 
60-mesh samples in the sequence MM4 $4_{60 \mathrm{~T}}<\mathrm{NA} 2_{60 \mathrm{~T}}<\mathrm{IL}-5_{60 \mathrm{~T}}<\mathrm{IL}-1_{60 \mathrm{~T}}$ (Fig. 4A), whereas parallel extractions of the respective 4-mesh samples yield no clear trend and sample IL- $5_{4 \mathrm{~T}}$ expresses a lower mesopore surface area than the less mature NA2 ${ }_{4 \mathrm{~T}}$ (Fig. 2A).

A comparison of mesopore size distributions of samples before and after extractions is presented in Fig. 5. The marginally mature sample MM4 shows almost no change in pore size distribution after solvent extractions for either size fraction (Fig. 5A, B) and exhibits relatively stable surface areas and mesopore volumes (Fig. 4). In turn, toluene-extracted sample $\mathrm{NA} 2_{4 \mathrm{~T}}$ documents the generation of pores with 7.5-87 nm diameters in its 4-mesh fraction (Fig. 5C). The toluene-extracted late mature sample IL- $5_{4 \mathrm{~T}}$ features opened pores most notably in the $16.6-90.3 \mathrm{~nm}$ size fraction (Fig. 5E), whereas toluene extraction of the 60-mesh fraction yielded no rearrangement of the mesopore size distribution (IL-560T; Fig. 5F). In post-mature sample IL-1, only the 60-mesh fraction and only mesopore sizes above $16.6 \mathrm{~nm}$ are notably affected after extractions with both solvents (Fig. 5H).

\subsection{Micropores}

Micropore characteristics were quantified by $\mathrm{CO}_{2}$ adsorption and low-pressure $\mathrm{CO}_{2}$ isotherms for the original, non-extracted samples for 4-mesh and 60-mesh fractions (Fig. 6A, B). Late mature samples of IL- $5_{\text {orig }}$ feature lowest and those of post-mature IL- $1_{\text {orig }}$ highest $\mathrm{CO}_{2}$ adsorption values, whereas marginally mature samples $\mathrm{MM} 4_{\text {orig }}$ and mature $\mathrm{NA} 2_{\text {orig }}$ express intermediate, similar $\mathrm{CO}_{2}$ adsorption.

DCM extraction caused an increase in $\mathrm{CO}_{2}$ adsorption for all samples (Fig. 7) 
regardless of size fraction. However, the increase declines in the order IL-1 $\mathrm{D}$ $($ post-mature $)>\mathrm{MM} 4_{\mathrm{D}}($ marginally mature $)>\mathrm{NA} 2_{\mathrm{D}}$ (early mature) $>$ IL- $5_{\mathrm{D}}$ (late mature) (Fig. 8A, B). Toluene extraction of the 4-mesh fractions caused further increases in the amount of adsorbed $\mathrm{CO}_{2}$ (Fig. 7A-D), except in the case of marginally mature $\mathrm{MM} 4_{4 \mathrm{~T}}$ for which the $\mathrm{CO}_{2}$ isotherm is almost identical to that of MM44D $(\mathrm{Fig}$. 7A). Toluene extraction of the 60-mesh fractions did not change, or slightly increased the amounts of adsorbed $\mathrm{CO}_{2}$ for samples relative to respective DCM-extracted 60-mesh fractions (Fig. 7E-H).

Micropore surface areas (Fig. 9A, B) and D-R micropore monolayer capacities (Fig. 9C, D) were calculated from low-pressure $\mathrm{CO}_{2}$ isotherms for all samples and increased after DCM extractions. Subsequent extractions with toluene caused little change, especially for 60-mesh fractions (Fig. 9B, D).

The DFT distribution of pore sizes within the micropore range (Fig. 10) indicates that DCM and toluene extractions of 4-mesh fractions increased pore volumes predominantly within the $0.5-0.7 \mathrm{~nm}$ and $0.8-0.9 \mathrm{~nm}$ pore size ranges. The smallest original micropore volume in late mature sample IL-5 $5_{\text {orig }}$ (Fig. 10E) increased only marginally during extractions, unlike other samples. In contrast to distinct increases in volumes of several micropore ranges in the 4-mesh fractions, both solvent extractions did not result in notable changes in 60-mesh fractions, except in marginally mature sample MM4 $4_{60 \mathrm{~T}}$ featuring an increase in micropore volume for the 0.55 to $0.85 \mathrm{~nm}$ pore size range (Fig. 10B).

\subsection{Soluble OM extracts}


FTIR analysis provides data about the distribution and abundances of chemical functional groups. Figure 11 illustrates the distribution of functional groups in $\mathrm{KBr}$ FTIR spectra of organic matter extracted by DCM and toluene. Each spectrum represents combined extracted OM from four studied samples. Of particular interest to this study are the aliphatic stretching region $\left(2800-3000 \mathrm{~cm}^{-1}\right)$, aromatic stretching region $\left(3000-3100 \mathrm{~cm}^{-1}\right)$ and the aromatic out-of-plane vibration region (700-900

$\mathrm{cm}^{-1}$ ). The aliphatic stretching region is used to calculate $\mathrm{CH}_{2} / \mathrm{CH}_{3}$ ratio that provides information about the chain length and the degree of branching of aliphatic compounds (Ganz and Kalkreuth, 1987; Guo and Bustin, 1998; Walker and Mastalerz, 2004). The $\mathrm{CH}_{2} / \mathrm{CH}_{3}$ ratio is higher for the primary DCM Soxhlet extract $\left(\mathrm{CH}_{2} / \mathrm{CH}_{3}=2.2\right)$ than for the secondary, sequential extract in toluene $\left(\mathrm{CH}_{2} / \mathrm{CH}_{3}=1.5\right)$. This indicates that the extract in DCM contains more long-chain and unbranched aliphatics, whereas the extract in toluene is rich in short-chain and highly branched aliphatics that may in part be present as side chains attached to larger, partially aromatic molecules. The aromatic carbon peak at $\sim 1600 \mathrm{~cm}^{-1}$ and aromatic out-of-plane bands between $750 \mathrm{~cm}^{-1}$ and $860 \mathrm{~cm}^{-1}$ are discernible only in the toluene extract.

\section{Discussion}

Three distinct processes result in the formation of different thermal products within shale during maturation (Jarvie et al., 2007): (1) the decomposition of kerogen to bitumen and gas; (2) the decomposition of bitumen to oil; (3) the decomposition of 
oil and bitumen to pyrobitumen and gas. Solid bitumen is assigned a position on a continuum between immature and post-mature stages (Curiale, 1986). Pyrobitumen is generated at higher maturity and contains only a minor amount of solvent-extractable matter (Jacob, 1989).

\subsection{Implications for the evolution of porosity during maturation}

The occupancy and blockage of pore spaces in shales by bitumen and oil may significantly affect customary porosity measurements based on adsorption of gases $\mathrm{N}_{2}$ and $\mathrm{CO}_{2}$. Presumably it also limits the penetration of metallic mercury $(\mathrm{Hg})$ used in conventional mercury capillary injection analyses. $\mathrm{N}_{2}$ and $\mathrm{Hg}$ have limited solubility in liquid and solid hydrocarbon phases, whereas $\mathrm{CO}_{2}$ and gaseous hydrocarbons have a stronger affinity to oil and bitumen (Svrcek and Mehrotra, 1982) and can dissolve into oil and bitumen-filled pores, especially under pressure and at low temperatures. It follows that traditional $\mathrm{N}_{2}$ and $\mathrm{Hg}$-based measures of porosity may be biased and have limited relevance for quantifying the ability of shale to store hydrocarbon gas if a significant portion of pores is affected by the presence of oil and bitumen. Sorption of gas onto shale is sensitive to pressure and temperature. Little published information could be found about the solubility of these gases in bitumen at conditions similar to those of our porosimetric analyses. However, we can estimate the amounts of methane, carbon dioxide, and nitrogen that can be dissolved in oil/bitumen in shales under source rock reservoir conditions with a hydrostatic pressure of $2 \mathrm{MPa}$ and a temperature of $23.9^{\circ} \mathrm{C}$ based on (i) the concentrations of extractable oil and bitumen in our shales (Table 3), (ii) Tharanivasan et al.'s (2006) measurements of $\mathrm{CO}_{2}$ 
solubility in heavy oil under reservoir conditions ( $3.25 \mathrm{wt} . \%$; Tharanivasan et al., 2006), and (iii) comparative data on the solubility of $\mathrm{N}_{2}$ in bitumen ( 0.21 wt.\%;

Svrcek and Mehrotra, 1982). This suggests that $\mathrm{CO}_{2}$ is $\sim 15$ times more soluble in fluid hydrocarbon phases than $\mathrm{N}_{2}$. Adsorption isotherm data based on $\mathrm{CO}_{2}$ are therefore far more affected by dissolution in hydrocarbons and less susceptible to blocking of hydrocarbon-filled pores than adsorption isotherm data using $\mathrm{N}_{2}$. Because of the large differences in $\mathrm{N}_{2}$ and $\mathrm{CO}_{2}$ solubilities in liquid hydrocarbons that are occupying some of the pore space in organic-rich shales within the oil window, traditional $\mathrm{N}_{2}$ and $\mathrm{CO}_{2}$-based porosity measurements underestimate the mesopore space (due to low $\mathrm{N}_{2}$ solubility) and overestimate the micropore space in shale where $\mathrm{CO}_{2}$ dissolving into fluid hydrocarbons mimicks $\mathrm{CO}_{2}$ adsorption along open pore surfaces. The apparent bias does not decrease until the onset of secondary cracking when fluid hydrocarbon phases transform to gas and pyrobitumen.

Our mesoporosity data for original, non-extracted shales qualitatively agree with recent studies (e.g., Furmann et al., 2013; Milliken et al., 2013; Valenza et al., 2013) and can be interpreted in terms of the evolution of OM-based porosity as a function of partial transformation of OM into hydrocarbons along maturation. Valenza et al. (2013) observed increased surface areas of shales after solvent extraction, especially noticeable within a $\mathrm{R}_{\mathrm{o}}$ range of $1.00-1.5 \%$, and attributed the effect to the opening of formerly bitumen-clogged pores. A similar increase in porosity is observed in our study. Our results demonstrate that pore filling along maturation modifies sample porosity from marginally mature MM4 $\left(\mathrm{R}_{\mathrm{o}}=0.55 \%\right)$ to post-mature IL-1 $\left(\mathrm{R}_{\mathrm{o}}=1.41 \%\right)$. 
However, maturity is not the only controlling factor. Our samples encompass a wide range of OM contents (TOC 4.3 to $13.0 \mathrm{wt}$ \%) that can influence the abundance of micropores and the measured porosity. Additional influential factors could be, for example, burial depth and depth-related pressure and temperature that are known to influence mesoporosity of coal in the Illinois Basin (Mastalerz et al., 2008), as well as the content of clay minerals that are known to contribute micropores in shales (Javadpour, 2009; Loucks et al., 2009; Mastalerz et al., 2013; Kuila and Prasad, 2013).

Soxhlet extraction of crushed shale with organic solvents removes soluble OM from pores that can be accessed by solvent. Closed pores will neither be affected by solvent extraction, nor are they recognized by traditional porosimetry. Higher maturity of shale tends to increase the molecular weight of hydrocarbon molecules in oil and bitumen via cross-linking and limits not only their solubility but also lowers their diffusion coefficient (Tharanivasan et al., 2006). Access of an organic solvent to poorly soluble, partially cross-linked bitumen and pyrobitumen in pores causes swelling of hydrocarbons and a decline of open porosity (Ertas et al., 2006). Therefore, it is mandatory to dry the solvent from shale after Soxhlet extraction and reverse the swelling prior to porosimetric measurements. In case of toluene extraction, we found it necessary to dry the Soxhlet-extracted shale in the vacuum of a freeze-dryer at room temperature for two days until the dry weight became constant. Careful gravimetric recording of the dry weight of shale samples after final drying and before extraction is not only important for quantification of Soxhlet-extracted soluble OM, but also to 
ascertain quantitative evaporation of the solvent.

Not only pore volume, but also pore surface area and pore size are important factors controlling the gas storage potential and sorption capacity of shales (Furmann et al., 2013; Yang et al., 2014). Higher surface area and smaller pore size enhance adsorption of gas molecules, and thus increase the gas adsorption potential in shales (Gregg and Sing, 1982). Comparisons of porosity parameters before and after solvent extractions of shales constrain the effects of hydrocarbon pore filling. Shales' responses to extractions by solvents with different boiling points and abilities to dissolve OM offer insight about the pore-filling materials. This study specifically differentiates low-temperature DCM-extractable OM from higher-temperature toluene-soluble OM. FTIR spectra of Soxhlet extracts confirm the presence of condensed polyaromatic structures in toluene extracts (Fig. 11). These lines of experimental evidence from solvent extractions of shales can jointly constrain and explain the evolution of pore filling with increasing maturity.

Our results demonstrate that mesoporosity and microporosity differ with regard to their responses to increasing maturity. Marginally mature sample $M M 4_{\text {orig }}$ has not yet generated significant amounts of oil. Consequently MM4 yielded little oil and bitumen during extraction with DCM and did not witness a significantly increased nitrogen adsorption volume or BET surface area in mesopores (Fig. 3A, E). The secondary extraction with higher-boiling toluene yielded a smaller extract compared to the first extract with DCM, implying that oil/bitumen remains highly soluble and has not yet intensively cross-linked and reduced its solubility at $\mathrm{R}_{0}=0.55 \%$. MM4's 
elevated TOC content is likely responsible for the observation that solvent extraction caused the strongest increase in microporosity (in absolute terms) among all shale samples, as indicated by $\mathrm{CO}_{2}$ adsorption data (Fig. 9A-F).

Analyses of Devonian Woodford Shale samples from Oklahoma in the oil window $\left(\mathrm{R}_{\mathrm{o}} \leq 0.90 \%\right)$ with focused ion beam milling (FIBM) and SEM suggested that organic porosity did not contribute to total porosity in shale (Curtis et al., 2011a). However, imaging sub-10 nm size pores in OM by SEM is challenging (Walters, 2013) due to low density of carbon and artifacts from $\mathrm{Au}$ or Pt coatings. Our sample NA2 $2_{\text {orig }}$ with somewhat lower maturity $\left(\mathrm{R}_{0}=0.65 \%\right)$ increased its BET surface area after extractions (NA2 ${ }_{4 \mathrm{~T}}$ and $\left.\mathrm{NA} 2_{60 \mathrm{~T}}\right)$ and thus indicated that some meso- and microporosity had been occupied by oil or extractable bitumen. Our observation suggests that this original shale harbors oil/bitumen-filled pores that would be undetectable with traditional SEM because electron microscopy does not see sufficient contrast between oil and other OM. In contrast to lower-maturity sample $M M 4_{\text {orig }}\left(\mathrm{R}_{\mathrm{O}}=0.55 \%\right)$, the extraction of oil/bitumen from NA2 $2_{\text {orig }}$ with toluene yielded more material from pores compared to DCM extraction (Fig. 3B, F), possibly due to the higher Soxhlet extraction temperature and efficiency when using toluene. In addition, as found previously for kerogen, bitumen becomes more aromatic (less aliphatic) and thus less soluble in DCM with increasing maturity. KBr-FTIR spectra of DCM and toluene Soxhlet extracts illustrate chemical differences between both extracts (Fig. 11). Toluene extracts exhibit elevated aromaticity (i.e., aromatic stretching region, aromatic out-of-plain region, and increased aliphatic chain length 
expressed as $\mathrm{CH}_{2} / \mathrm{CH}_{3}$ ratio), indicating that hot aromatic toluene is a better solvent than cooler DCM for extracting cross-linked bitumen. The gains in BET surface area in shales due to secondary toluene extraction increase with maturity (Table 5, bottom row) in agreement with Feng et al.'s (2013) observation that the average aliphatic chain length in bitumen shortens with increasing maturity when bitumen is thermally decomposing.

Positive relationships are expected between OM content and total porosity, or between OM content and micropore or mesopore volumes (Chalmers and Bustin, 2007; Ross and Bustin, 2009; Milliken et al., 2013). The relationship between micropore surface area and TOC may explain the greatly enhanced micropore surface area and monolayer capacity of TOC-rich sample MM4 (Fig. 9A-D). High TOC in MM4 did not cause, however, enhanced mesoporosity compared to lower-TOC samples. The absence of a strong relationship between mesopore volume and TOC may be due to differences in maturity.

We interpret the lowest observed meso- and microporosities in late mature sample IL- $5_{\text {orig }}\left(\mathrm{R}_{0}=1.15 \%\right.$; Figs. $2 \mathrm{~A}, 4 \mathrm{~A}$; Fig. 9A, B $)$ to be a result of pores being partially or entirely occupied/blocked by oil and bitumen. Shale IL- $5_{\text {orig }}$ has the lowest meso and micro-porosity values among all four samples because its higher maturity provided liquid hydrocarbons to occupy pore space. Secondary toluene extraction significantly increased mesoporosity in IL-5 $5_{\mathrm{T}}$ and allows us to conclude that mesopores in IL-5 $5_{\text {orig }}$ are occupied by bitumen with limited solubility in DCM. In contrast to observed differences in extraction efficiencies between toluene and DCM 
for bitumen-filled mesopores, toluene could not extract significant amounts of additional aromatic bitumen than DCM from micropores, as indicated by limited to no increase in micropore surface area after toluene extraction (Fig. 9A, B). One possible reason is that micropores are too small or marginally connected to allow efficient penetration of solvents and diffusive removal of solutes.

\subsection{Effect of shale particle size on measured pore parameters}

For non-extracted shales, crushing and sieving from 4-mesh to 60-mesh has a limited effect on shales' microporosity, which is confirmed by the observation that the evolutionary trends in microporosity of both size fractions with increasing thermal maturity are generally similar for samples before extractions (Fig. 9A-F). In contrast, grinding and dry-sieving of shale samples from 4-mesh to 60-mesh resulted in significantly higher mesopore volumes and mesopore surface areas (Figs. 2A, B; 4A, B) in agreement with the concept of facilitated access of gas to mesopores after grinding. A contributing factor may be incomplete equilibration of the interior of larger shale particles (e.g., 4-mesh fraction) during gas adsorption porosimetry (Chen et al., in review; Clarkson and Bustin, 1999), whereas 60-mesh particles can more readily attain adsorption equilibrium with $\mathrm{N}_{2}$ and provide more reliable mesopore data.

Particle size also limits the ability of organic solvents to efficiently extract soluble OM from the interior of dense shale particles. Smaller particle size offers a larger surface area and reduces the path length of solvent penetration and diffusive removal of solutes from pores in the center of particles. Smaller grain size of crushed 
shale, higher-boiling point of the solvent (Tamimi and Uysal, 1990), and the aromatic structure of the solvent (i.e., toluene) improve the oil/bitumen extraction efficiency. The difficulty of DCM-extraction of hydrocarbons from the 4-mesh fraction of IL-5 $5_{\text {orig }}$ is indicated by small increases in both mesopore and micropore surface areas after extraction (Figs. 2A, 9A). Possibly some pore space is rendered inaccessible by mineral blockage (Curtis et al., 2012) or via encapsulation in impermeable clay within the shale matrix (Klaver et al., 2012). Furthermore, relative to toluene-extracted 4-mesh fractions, the toluene-extracted 60-mesh fractions show decreased mesopore volumes, increased micropore volumes (Fig. 4B), and decreased mesopore sizes (Fig. 5B, D, F, H; Table 4). Similarly, DCM-extraction of soluble OM from high volatile bituminous coals with $\mathrm{R}_{\mathrm{o}}=0.69 \%$ reduced the BET surface areas and mesopore volumes due to progressive opening of larger pores (Furmann et al., 2013). Perhaps the removal of oil/bitumen from mesopores in our 60-mesh shale fractions enlarged the open pore space to enter the macropore range, thus resulting in decreased mesopore volumes after extraction (Fig. 4B). A similar shift in open pore volume may be responsible for declined micropore volumes in 4-mesh shale fractions after extractions (Fig. 9E). A finer grain size of 60-mesh is not only beneficial for efficient solvent extraction of soluble OM, but also kinetically favors gas adsorption equilibration of the interior of shale particles (Chen et al., in review), and therefore is more appropriate for gas adsorption porosimetry for both unextracted and extracted shales. 


\section{Conclusions}

Consecutive Soxhlet-extractions with dichloromethane and toluene have been applied to two grain size fractions of a suite of New Albany Shale samples spanning a range of thermal maturity in order to evaluate the influence of extractable organic matter on the evolution of porosity in shales. The following conclusions have been reached:

1. Mesopore volumes in Soxhlet-extracted shales indicate that mesoporosity in original, unextracted shales follows a non-monotonous evolutionary path with increasing thermal maturity in response to primary cracking of kerogen and secondary cracking of bitumen. The TOC content is less influential on mesopores volumes than on micropore volumes. Thermal maturity affects microporosity during the post-mature stage as secondary cracking of OM produces additional micropores. The occupation of pores by oil and bitumen during the early mature stage prior to significant generation of oil and bitumen affects mesoporosity only slightly, and this influence becomes strongest during the late mature stage.

2. Soxhlet extraction with higher-boiling point toluene more aggressively removes marginally soluble organic matter from shale than lower-boiling DCM. KBr-FTIR spectra of DCM and toluene Soxhlet extracts illustrate that the oil and bitumen in toluene extracts exhibit elevated aromaticity that may be linked to enhanced cross-linking of organic matter with reduced solubility in DCM. The average aliphatic chain length in extracted organic matter 
increases during early maturation but later shortens with increasing maturity when bitumen is thermally decomposing.

3. Particle size significantly impacts gas adsorption results and surface area and mesopore characteristics in particular. Mesopore volumes increase as particle size decreases from 4-mesh to 60-mesh. Different particle size fractions of unextracted shale samples exhibit contrasting mesoporosity trends with increasing maturity. Finer grain size improves the efficiency of solvent extraction as smaller particles offer a larger surface area and reduce the distance of solvent penetration and diffusive removal of solutes from the center of particles. In addition, particles can more readily attain adsorption equilibrium with $\mathrm{N}_{2}$ and provide more reliable mesopore data. In contrast, the respective trends for micropore volumes of the two size fractions do not exhibit large differences.

In summary, thermal maturity is an important factor controlling total porosity in organic-rich shales. However, the simultaneous effects of other factors demand that reliable predictions of adsorbed gas capacities of shales need to be based jointly on the multitude of factors, including kerogen type, lithostatic pressure, organic matter (or total organic carbon) content, mineralogy, and thermal maturity.

\section{Acknowledgements}


Financial support from the China Scholarship Council (CSC) for L. W. and Y. C. is gratefully acknowledged. This study was partially supported by U.S. Department of Energy, Office of Science, Office of Basic Energy Sciences under Award Number Grant DE-SC0006978 (formerly DE-FG02-11ER16246).

\section{References}


Bernard, S., Horsfield, B., Schulz, H.-M., Wirth, R., Schreiber, A., Sherwood, N., 2012. Geochemical evolution of organic-rich shales with increasing maturity: A STXM and TEM study of the Posidonia Shale (Lower Toarcian, northern Germany). Marine and Petroleum Geology 31, 70 $\square 89$. http://dx.doi.org/10.1016/j.marpetgeo.2011.05.010.

Bustin, R.M., Bustin, A.M.M., Cui, A., Ross, D., Pathi, V.M., 2008. Impact of shale properties on pore structure and storage characteristic. SPE Shale Gas Production Conference. Society of Petroleum Engineers, Fort Worth, USA. SPE 119892-MS. http://dx.doi.org/10.2118/119892-MS.

Chalmers, G.R.L., Bustin, R.M., 2007. The organic matter distribution and methane capacity of the Lower Cretaceous strata of Northeastern British Columbia, Canada. International Journal of Coal Geology 70, 223 $\square 239$. http://dx.doi.org/10.1016/j.coal.2006.05.001.

Chalmers, G.R.L., Bustin, R.M., 2008. Lower Cretaceous gas shales in northeastern British Columbia, Part I: geological controls on methane sorption capacity. Bulletin of Canadian Petroleum Geology 56, $1 \square 21$. http://dx.doi.org/10.2113/gscpgbull.56.1.1.

Chalmers, G.R., Bustin, R.M., Power, I.M., 2012. Characterization of gas shale pore systems by porosimetry, pycnometry, surface area, and field emission scanning electron microscopy/transmission electron microscopy image analyses: Examples from the Barnett, Woodford, Haynesville, Marcellus, and Doig units. AAPG Bulletin 96, 1099 $\square$ 1119. http://dx.doi.org/10.1306/10171111052. 
Chen, Y., Mastalerz, M., Schimmelmann, A., 2012. Characterization of chemical functional groups in macerals across different coal rank via micro-FTIR spectroscopy. International Journal of Coal Geology 104, 22-33. http://dx.doi.org/10.1016/j.coal.2012.09.001.

Chen, Y., Wei, L., Mastalerz, M., Schimmelmann, A., 2014. The effect of particle size on low pressure $\mathrm{N}_{2}$ and $\mathrm{CO}_{2}$ gas adsorption porosimetry of New Albany Shale. International Journal of Coal Geology (in review).

Clarkson, C.R., Bustin, R.M., 1999. The effect of pore structure and gas pressure upon the transport properties of coal: a laboratory and modeling study. 1. Isotherms and pore volume distributions. Fuel 78, $1333 \square 1344$.

Clarkson, C.R., Solano, N., Bustin, R.M., Bustin, A.M.M., Chalmers, G.R.L., He, L., Melnichenko, Y.B., Radliński, A.P., Blach, T.P., 2013. Pore structure characterization of North American shale gas reservoirs using USANS/SANS, gas adsorption, and mercury intrusion. Fuel 103, 606 $\square 616$. http://dx.doi.org/10.1016/j.fuel.2012.06.119.

Curtis, M.E., Ambrose, R.J., Sondergeld, C.H., Rai, C.S., 2011a. Transmission and Scanning Electron Microscopy investigation of pore connectivity of gas shales on the nanoscale. North American Unconventional Gas Conference and Exhibition. Society of Petroleum Engineers, The Woodlands, Texas, USA. SPE 144391-MS. http://dx.doi.org/10.2118/144391-MS.

Curtis, M.E., Ambrose, R.J., Sondergeld, C.H., Rai, C.S., 2011b. Investigation of the relationship between organic porosity and thermal maturity in the Marcellus 
Shale. North American Unconventional Gas Conference and Exhibition. Society of Petroleum Engineers, The Woodlands, Texas, USA. SPE 144370-MS. http://dx.doi.org/10.2118/144370-MS.

Curiale, J.A., 1986. Origin of solid bitumens, with emphasis on biological marker results. Organic geochemistry $10,599 \square 580$. http://dx.doi.org/10.1016/0146-6380(86)90054-9.

Curtis, M.E., Cardott, B.J., Sondergeld, C.H., Rai, C.S., 2012. Development of organic porosity in the Woodford Shale with increasing thermal maturity. International Journal of Coal Geology 103, $26 \square 31$. http://dx.doi.org/10.1016/j.coal.2012.08.004.

Ertas, D., Kelemen, S.R., Halsey, T.C., 2006. Petroleum expulsion part 1. Theory of kerogen swelling in multicomponent solvents. Energy \& Fuels 20, $295 \square 300$. http://dx.doi.org/10.1021/ef058024k.

Feng, Y., Le Doan, T.V., Pomerantz, A.E., 2013. The chemical composition of bitumen in pyrolyzed Green River oil shale: Characterization by ${ }^{13} \mathrm{C}$ NMR spectroscopy. Energy \& Fuels 27, 7314 $\square 7323$. http://dx.doi.org/10.1021/ef4016685.

Fishman, N.S., Hackley, P.C., Lowers, H.A., Hill, R.J., Egenhoff, S.O., Eberl, D.D., Blum, A.E., 2012. The nature of porosity in organic-rich mudstones of the Upper Jurassic Kimmeridge Clay Formation, North Sea, offshore United Kingdom. International Journal of Coal Geology 103, 32 $\square 50$. http://dx.doi.org/10.1016/j.coal.2012.07.012. 
Furmann, A., Mastalerz, M., Brassell, S.C., Schimmelmann, A., Picardal, F., 2013. Extractability of biomarkers from high- and low-vitrinite coals and its effect on the porosity of coal. International Journal of Coal Geology 107, $141 \square 151$. http://dx.doi.org/10.1016/j.coal.2012.09.010.

Ganz, H., Kalkreuth, W., 1987. Application of infrared spectroscopy to the classification of kerogen-types and the evaluation of source rock and oil shale. Fuel 66, 708-711.

Gregg, S.J., Sing, K.S.W., 1982. Adsorption, Surface Area and Porosity. Academic Press, London.

Guo, Y., Bustin, R.M., 1998. Micro-FTIR spectroscopy of liptinite macerals in coal. International Journal of Coal Geology 36, 259-275.

Hunt, J.M., 1995. Petroleum Geochemistry and Geology, second ed., W. H. Freeman and Company, New York.

Jacob, H., 1989. Classification, structure, genesis and practical importance of natural solid oil bitumen (“migrabitumen”). International Journal of Coal Geology 11, 65 $\square 79$. http://dx.doi.org/10.1016/0166-5162(89)90113-4.

Jarvie, D.M., 2012. Shale resource systems for oil and gas: Part $2 \square$ Shale-oil resource systems, in: Breyer, J.A. (Ed.), Shale Reservoirs $\square$ Giant Resources for the 21st Century. AAPG Memoir 97, Tulsa, pp. 89 $\square 119$.

Jarvie, D.M., Hill, R.J., Ruble, T.E., Pollastro, R.M., 2007. Unconventional shale-gas systems: The Mississippian Barnett Shale of north-central Texas as one model for 
thermogenic shale-gas assessment. AAPG Bulletin 91, 475 $\square 499$, http://dx.doi.org/10.1306/12190606068.

Jarvie, D.M., Coskey, R.J., Johnson, M.S., Leonard, J.E., 2011. The geology and geochemistry of the Parshall area, Mountrail County, North Dakota, in: Robinson, J.W., LeFever, J.A., and Gaswirth, S.B. (Eds.), The Bakken-Three Forks petroleum system in the Williston Basin. Rocky Mountain Association of Geologists, Denver, pp. 229 $\square 281$.

Javadpour, F., 2009. Nanopores and apparent permeability of gas flow in mudrocks (shales and siltstone). Journal of Canadian Petroleum Technology 48, $16 \square 21$. http://dx.doi.org/10.2118/09-08-16-DA.

Klaver, J., Desbois, G., Urai, J.L., Littke, R., 2012. BIB-SEM study of the pore space morphology in early mature Posidonia Shale from the Hils area, Germany. International Journal of Coal Geology 103, $12 \square 25$. http://dx.doi.org/10.1016/j.coal.2012.06.012.

Kuila, U., Prasad, M., 2013. Specific surface area and pore-size distribution in clays and shales. Geophysical Prospecting 61, 341 $\square 362$. http://dx.doi.org/10.1111/1365-2478.12028.

Lasswell, P.M., 2011. Shale routine \& special core analysis. http://www.csur.com/images/Technical_Luncheons/Presentations/2011/Shale_Pre sentation_02.09.11.pdf (accessed on 4 July 2014).

Loucks, R.G., Reed, R.M., Ruppel, S.C., Jarvie, D.M., 2009. Morphology, genesis, and distribution of nanometer-scale pores in siliceous mudstones of the Mississippian 
Barnett Shale. Journal of Sedimentary Research 79, 848 $\square$ 861. http://dx.doi.org/ 10.2110/jsr.2009.092.

Loucks, R.G., Reed, R.M., Ruppel, S.C., Hammes, U., 2012. Spectrum of pore types and networks in mudrocks and a descriptive classification for matrix-related mudrock pores. AAPG Bulletin 96, 1071 $\square 1098$. http://dx.doi.org/10.1306/08171111061.

Mastalerz, M., Drobniak, A., Strąpoć, D., Acosta W.S., Rupp J., 2008. Variations in pore characteristics in high volatile bituminous coals: Implications for coal bed gas content. International Journal of Coal Geology 76, 205-216. http://dx.doi.org/10.1016/j.coal.2008.07.006.

Mastalerz, M., He, L., Melnichenko, Y.B., Rupp, J.A., 2012. Porosity of coal and shale: Insights from gas adsorption and SANS/USANS techniques. Energy \& Fuels 26, 5109 $\square 5120$. http://dx.doi.org/10.1021/ef300735t.

Mastalerz, M., Schimmelmann, A., Drobniak, A., Chen, Y., 2013. Porosity of Devonian and Mississippian New Albany Shale across a maturation gradient: Insights from organic petrology, gas adsorption, and mercury intrusion. AAPG Bulletin 97, $1621 \square 1643$. http://dx.doi.org/10.1306/04011312194.

Melnichenko, Y.B., Radlinski, A.P., Mastalerz, M., Cheng, G., Rupp. J., 2009. Characterization of the $\mathrm{CO}_{2}$ fluid adsorption in coal as a function of pressure using neutron scattering techniques (SANS and USANS). International Journal of Coal Geology 77, 69 $\square 79$. http://dx.doi.org/10.1016/j.coal.2008.09.017. 
Milliken, K.L., Rudnicki, M., Awwiller, D.N., Zhang, T., 2013. Organic matter-hosted pore system, Marcellus Formation (Devonian), Pennsylvania. AAPG Bulletin 97, 177 $\square$ 200. http://dx.doi.org/10.1306/07231212048.

Modica, C.J., Lapierre, S.G., 2012. Estimation of kerogen porosity in source rocks as a function of thermal transformation: Example from the Mowry Shale in the Powder River Basin of Wyoming. AAPG Bulletin 96, 87 $\square 108$. http://dx.doi.org/10.1306/04111110201.

Orr, C., 1977. Pore size and volume measurement, in: Kolthoff, I.M., Elving, P.J., Stross, F.H. (Eds.), Treatise on Analytical Chemistry Part III, vol. 4. John Wiley and Sons, New York, pp. $321 \square 358$.

Passey, Q.R., Bohacs, K., Esch, W.L., Klimentidis, R., Sinha, S., 2010. From oil-prone source rock to gas-producing shale reservoir $\square$ geologic and petrophysical characterization of unconventional shale-gas reservoirs. International Oil and Gas Conference and Exhibition. Society of Petroleum Engineers, Beijing, China. SPE 131350-MS. http://dx.doi.org/10.2118/131350-MS.

Pollastro, R.M., Jarvie, D.M., Hill, R.J., Adams, C.W., 2007. Geologic framework of the Mississippian Barnett Shale, Barnett-Paleozoic total petroleum system, Bend arch-Fort Worth Basin, Texas. AAPG Bulletin 91, 405 $\square 436$. http://dx.doi.org/10.1306/10300606008.

Ross, D.J.K., Bustin, R.M., 2009. The importance of shale composition and pore structure upon gas storage potential of shale gas reservoirs. Marine and Petroleum Geology 26, 916 $\square 927$. http://dx.doi.org/10.1016/j.marpetgeo.2008.06.004. 
Romero-Sarmiento, M.-F., Ducros, M., Carpentier, B., Lorant, F., Cacas, M.-C., Pegaz-Fiornet, S., Wolf, S., Rohais, S., Moretti, I., 2013. Quantitative evaluation of TOC, organic porosity and gas retention distribution in a gas shale play using petroleum system modeling: Application to the Mississippian Barnett Shale. Marine and Petroleum Geology 45, 315 $\square 330$. http://dx.doi.org/10.1016/j.marpetgeo.2013.04.003.

Slatt, R.M., O’Brien, N.R., 2011. Pore types in the Barnett and Woodford gas shales: Contribution to understanding gas storage and migration pathways in fine-grained rocks. AAPG Bulletin 95, 2017 $\square 2030$, http://dx.doi.org/10.1306/03301110145.

Svrcek, W.Y., Mehrotra, A.K., 1982. Gas solubility, viscosity and density measurements for Athabasca bitumen. Journal of Canadian Petroleum Technology 21, 31-38. http://dx.doi.org/10.2118/82-04-02.

Tamimi, A., Uysal, B.Z., 1990. Parametric investigation of oil-shale extraction with organic solvents. Separation science and technology 25, $1151 \square 1159$.

Tharanivasan, A.K., Yang, C., Gu, Y., 2006. Measurements of molecular diffusion coefficients of carbon dioxide, methane, and propane in heavy oil under reservoir conditions. Energy \& Fuels 20, 2509 $\square 2517$. http://dx.doi.org/10.1021/ef060080d.

Valenza, J. J., Drenzek, N., Marques, F., Pagels, M., Mastalerz, M., 2013. Geochemical controls on shale microstructure. Geology $41,611 \square 614$. http://dx.doi.org/10.1130/G33639.1.

Walters, C.C., 2013. New insights on gas storage and transport in shales: Goldschmidt 2013 Conference, Abstracts, p. 2443. 
http://goldschmidt.info/2013/abstracts/finalPDFs/2443.pdf

Walker, R., Mastalerz, M., 2004. Functional group and individual maceral chemistry of high volatile bituminous coals from southern Indiana: controls on coking. International Journal of Coal Geology 58, 181-191.

Wang, F.P., Reed, R.M., 2009. Pore networks and fluid flow in gas shales. SPE Annual Technical Conference and Exhibition. Society of Petroleum Engineers, New Orleans, Louisiana, USA. SPE 124253-MS. http://dx.doi.org/10.2118/124253-MS.

Webb, P.A., Orr, C., 1997. Analytical Methods in Fine Particle Technology. Micromeritics Instrument Corporation, Norcross, Georgia, USA.

Yang, F., Ning, Z., Liu, H., 2014. Fractal characteristics of shales from a shale gas reservoir in the Sichuan Basin, China. Fuel 115, 378 $\square 384$. http://dx.doi.org/10.1016/j.fuel.2013.07.040.

Figure 1. Low-pressure $\mathrm{N}_{2}$ adsorption isotherms of shale samples. $\mathrm{P}=$ actual gas pressure; $\mathrm{P}_{\mathrm{o}}=$ vapor pressure of the adsorbing gas. STP: standard ambient temperature and pressure $\left(25^{\circ} \mathrm{C}\right.$ and $\left.100 \mathrm{kPa}\right)$. We use subscript numbers after sample acronyms to distinguish between 4 and 60-mesh fractions and additionally mark original samples before extraction (e.g., MM4 $4_{4 \text { orig }}$ and $M M 4_{60 \text { orig }}$ ). Solvent-extracted samples are characterized by additional subscript letters $\mathrm{D}$ for dichloromethane and $\mathrm{T}$ for toluene (e.g., $M M 4_{4 \mathrm{D}}$ and $\mathrm{MM} 4_{60 \mathrm{~T}}$ ).

Figure 2. (A) BET surface area and (B) BJH mesopore volume of 4 mesh shale 
samples before extractions and after DCM and toluene extractions.

Figure 3. Low-pressure $\mathrm{N}_{2}$ adsorption isotherms of shale samples before extractions and after DCM and toluene solvents extractions for 4 mesh (A-D) and 60 mesh samples $(\mathrm{E}-\mathrm{H}) . \mathrm{P}=$ actual gas pressure; $\mathrm{P}_{\mathrm{o}}=$ vapor pressure of the adsorbing gas .

Figure 4. (A) BET surface area and (B) BJH mesopore volume of 60 mesh shale samples before extractions and after DCM and toluene extractions.

Figure 5. Incremental mesopore volumes of shale samples obtained by low pressure $\mathrm{N}_{2}$ adsorption porosimetry.

Figure 6. Low-pressure $\mathrm{CO}_{2}$ adsorption isotherms of shale samples. $\mathrm{P}=$ actual gas pressure; $\mathrm{P}_{\mathrm{O}}=$ vapor pressure of the adsorbing gas. STP: standard ambient temperature and pressure $\left(25^{\circ} \mathrm{C}\right.$ and $\left.100 \mathrm{kPa}\right)$.

Figure 7. Low-pressure $\mathrm{CO}_{2}$ adsorption isotherms of shale samples before and after DCM, toluene extractions for 4 mesh (A-D) and 60 mesh (E-H). P = actual gas pressure; $\mathrm{P}_{\mathrm{o}}=$ vapor pressure of the adsorbing gas. STP: standard ambient temperature and pressure $\left(25^{\circ} \mathrm{C}\right.$ and $\left.100 \mathrm{kPa}\right)$.

Figure 8. Low-pressure $\mathrm{CO}_{2}$ adsorption isotherms of shale samples before and after extraction for 4 mesh $(\mathrm{A}$ and $\mathrm{C})$ and 60 mesh $(\mathrm{B}$ and $\mathrm{D}) . \mathrm{P}=$ actual gas pressure; $\mathrm{P}_{\mathrm{O}}=$ vapor pressure of the adsorbing gas. STP: standard ambient temperature and pressure $\left(25^{\circ} \mathrm{C}\right.$ and $\left.100 \mathrm{kPa}\right)$.

Figure 9. Micropore charcateristics: Dubinin-Radushkevich (D-R) surface area $\left(\mathrm{m}^{2} / \mathrm{g}\right)$, Dubinin-Radushkevich monolayer capacity $\left(\mathrm{cm}^{3} / \mathrm{g}\right)$, and Dubinin-Astakhov (D-A) volume $\left(\mathrm{cm}^{3} / \mathrm{g}\right)$ of shale samples before extractions and after DCM and toluene extractions. 
Figure 10. Incremental micropore volumes of shale samples obtained by low pressure $\mathrm{CO}_{2}$ adsorption porosimetry.

Figure 11. KBr-Fourier transform infrared (FTIR) spectrometry of combined extracted OM from four studied samples in solvents dichloromethane (DCM) and toluene. Each spectrum represents the difference between the extract in solution and the spectrum of the respective pure solvent (e.g., the extract in DCM minus the spectrum of pure DCM). Aliphatic C-H stretching exhibits peaks at $\sim 2922 \mathrm{~cm}^{-1}$ and $2860 \mathrm{~cm}^{-1}$. Aromatic carbon peaks at $\sim 1600 \mathrm{~cm}^{-1}$, whereas aromatic out-of-plane vibrations appear between $750 \mathrm{~cm}^{-1}$ and $860 \mathrm{~cm}^{-1}$. 
BET surface areas of original and extracted shales
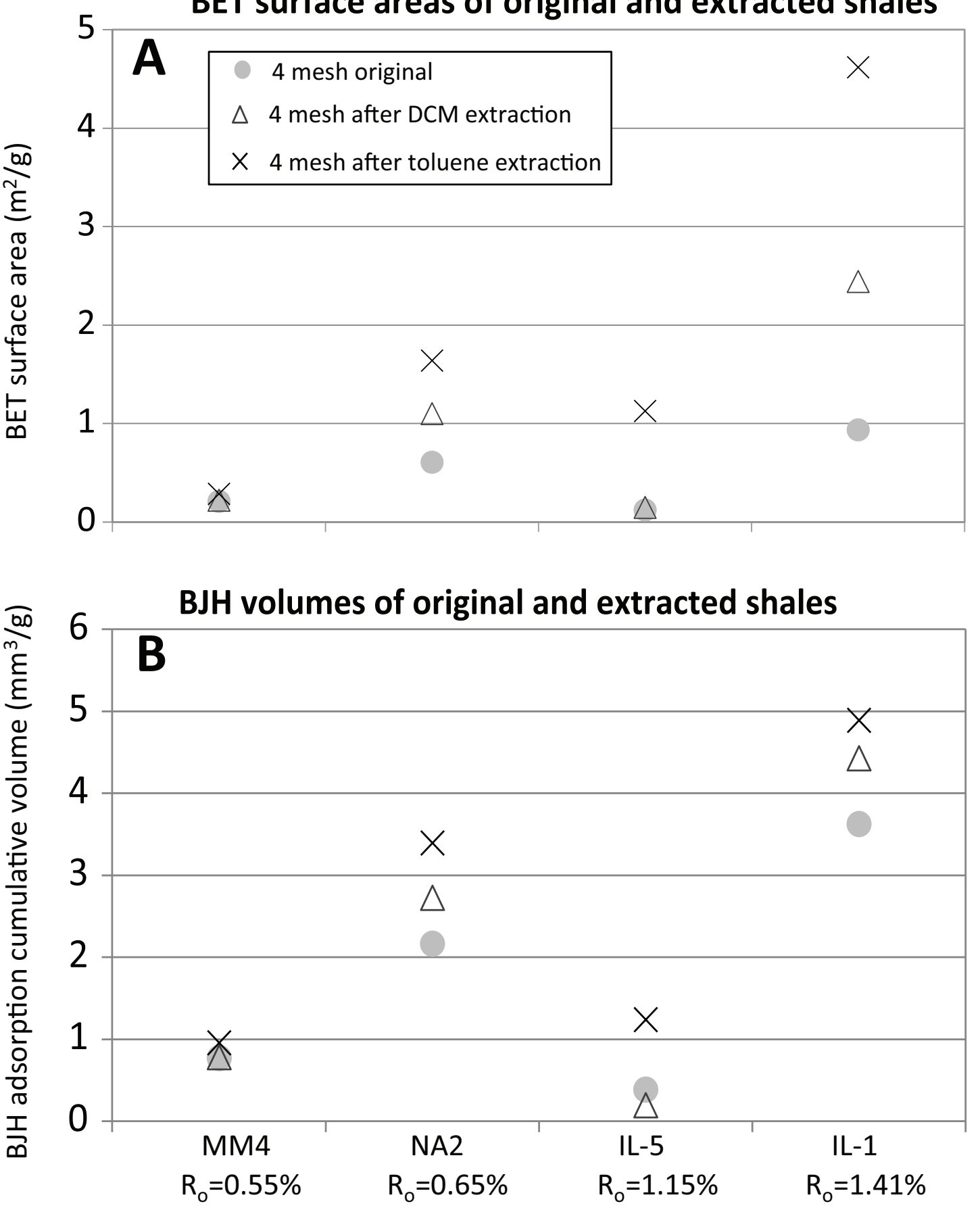
Figure $\left.3{ }^{4}\right] \quad \boldsymbol{A} \quad$ MM4 4 mesh
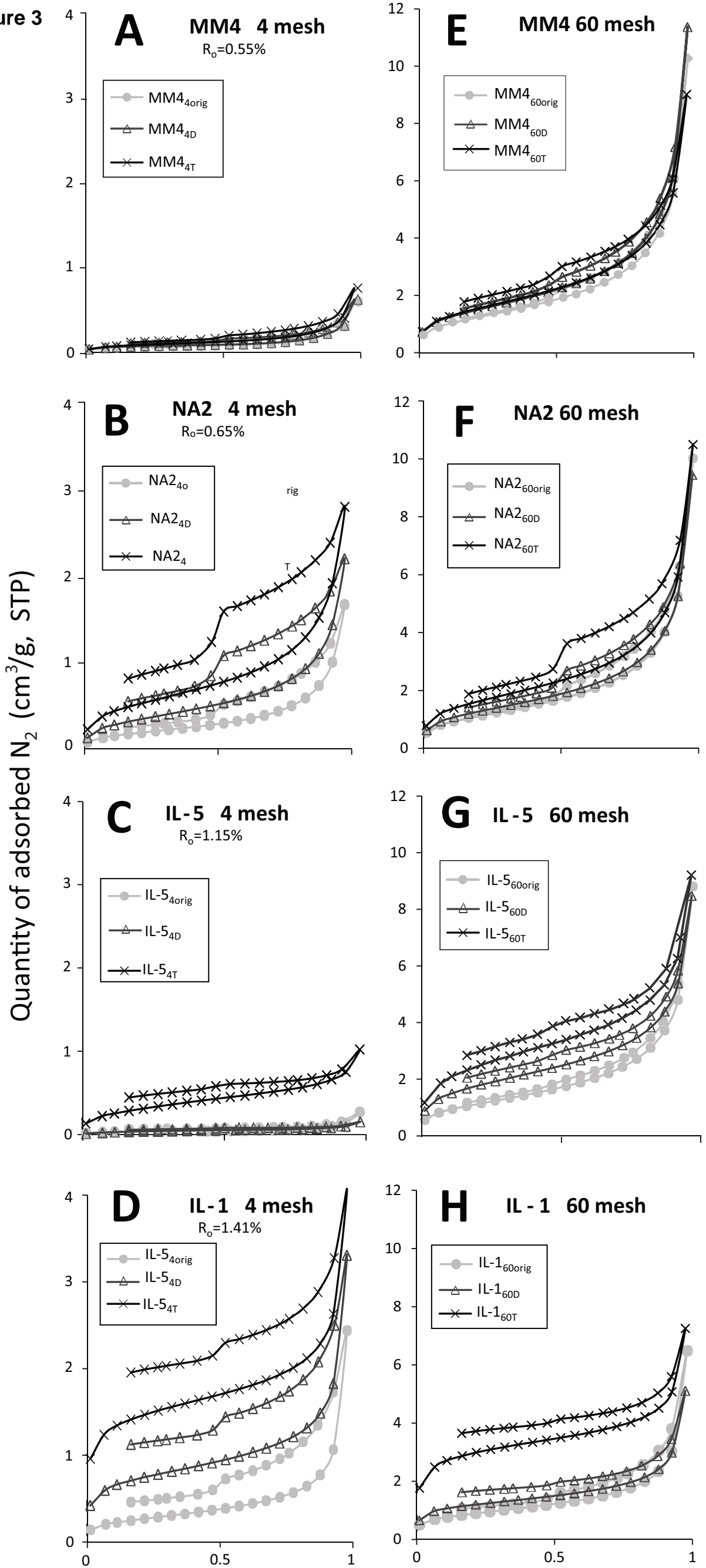

Relative pressure $\left(\mathrm{P} / \mathrm{P}_{\mathrm{o}}\right)$ 


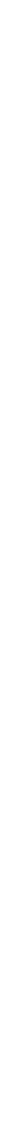

\section{BJH volumes of original and extracted shales}

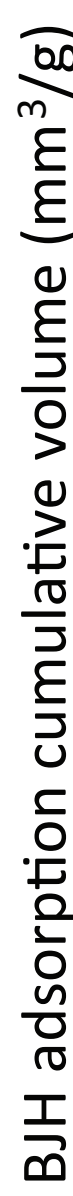

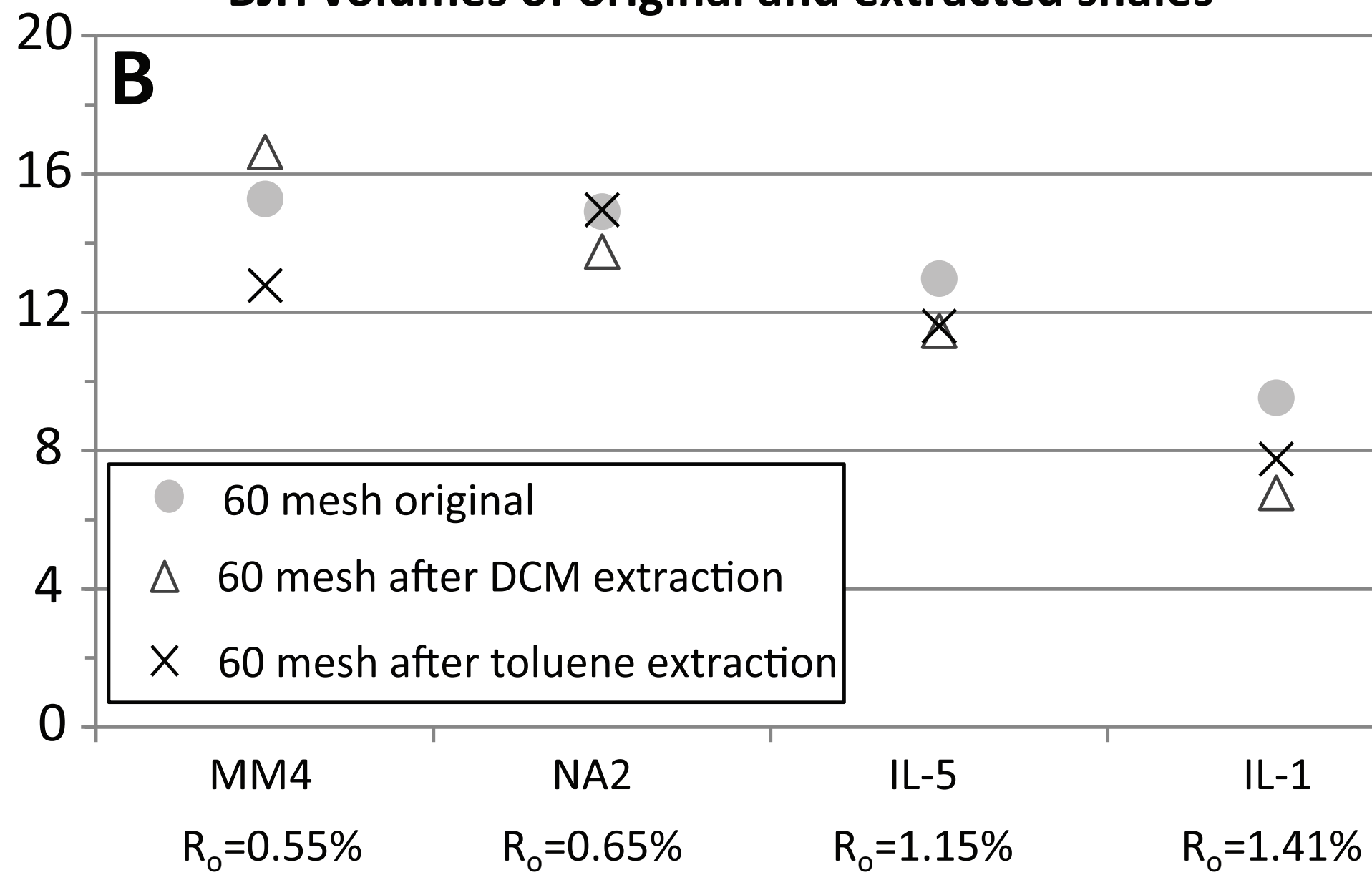




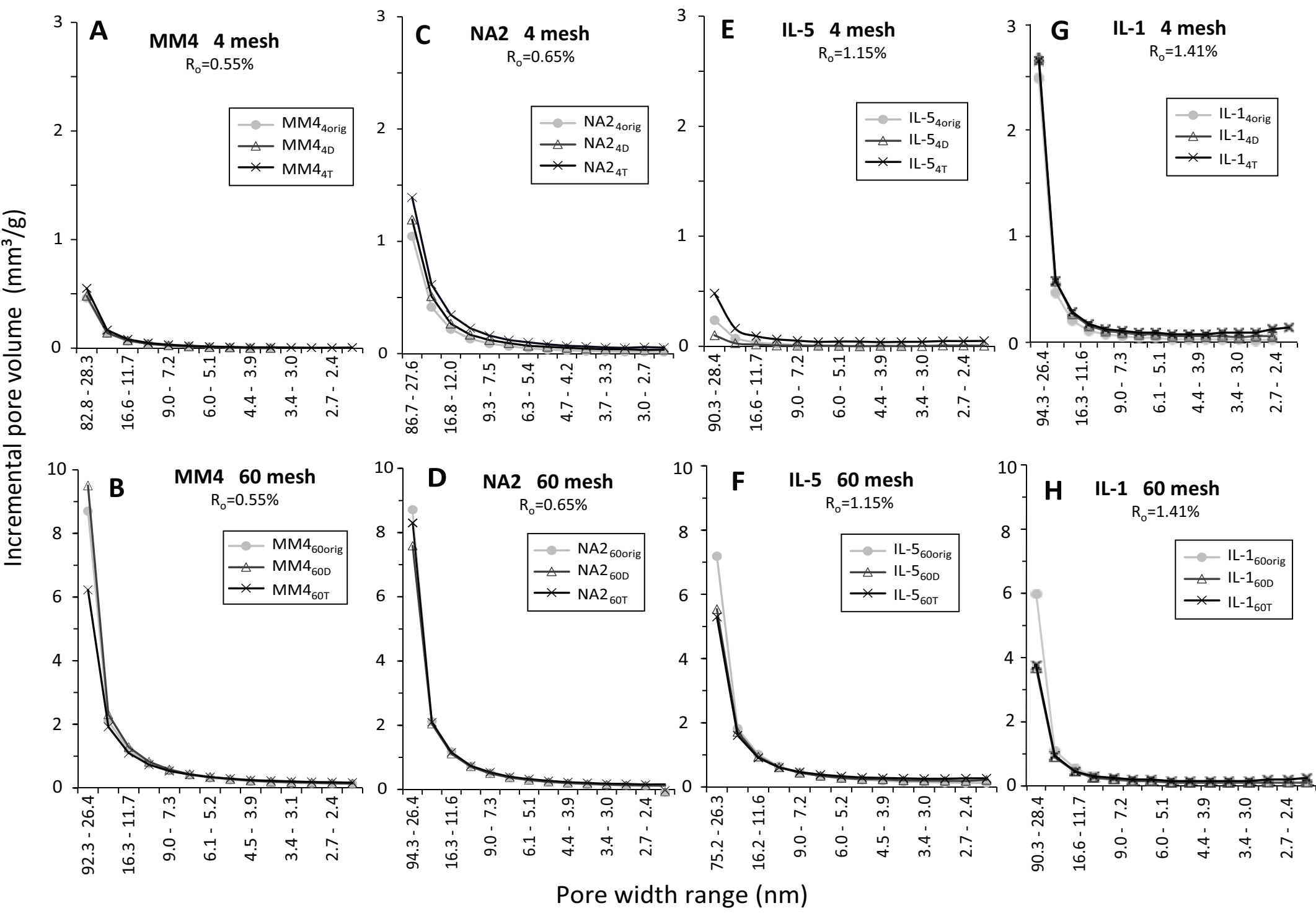




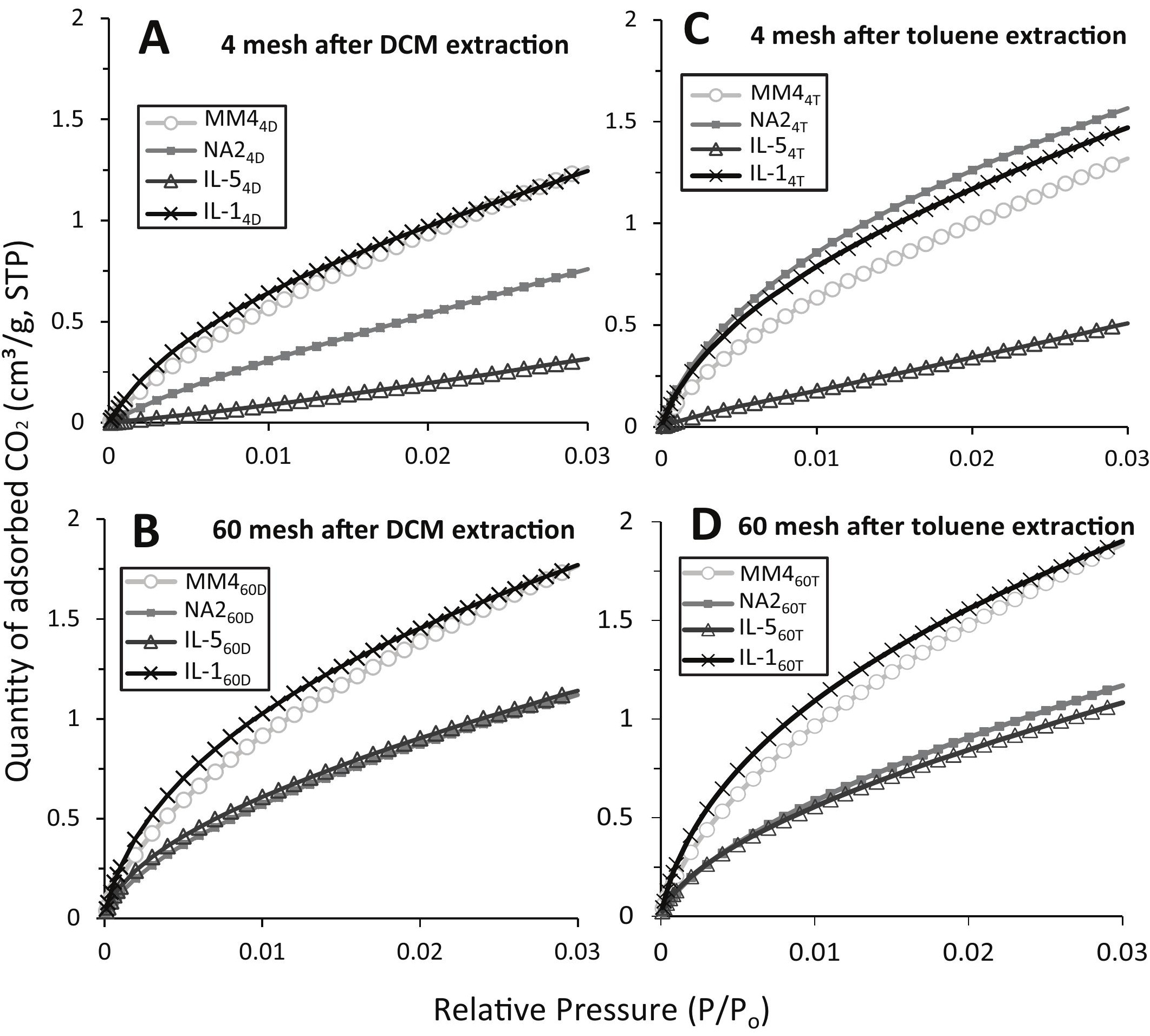




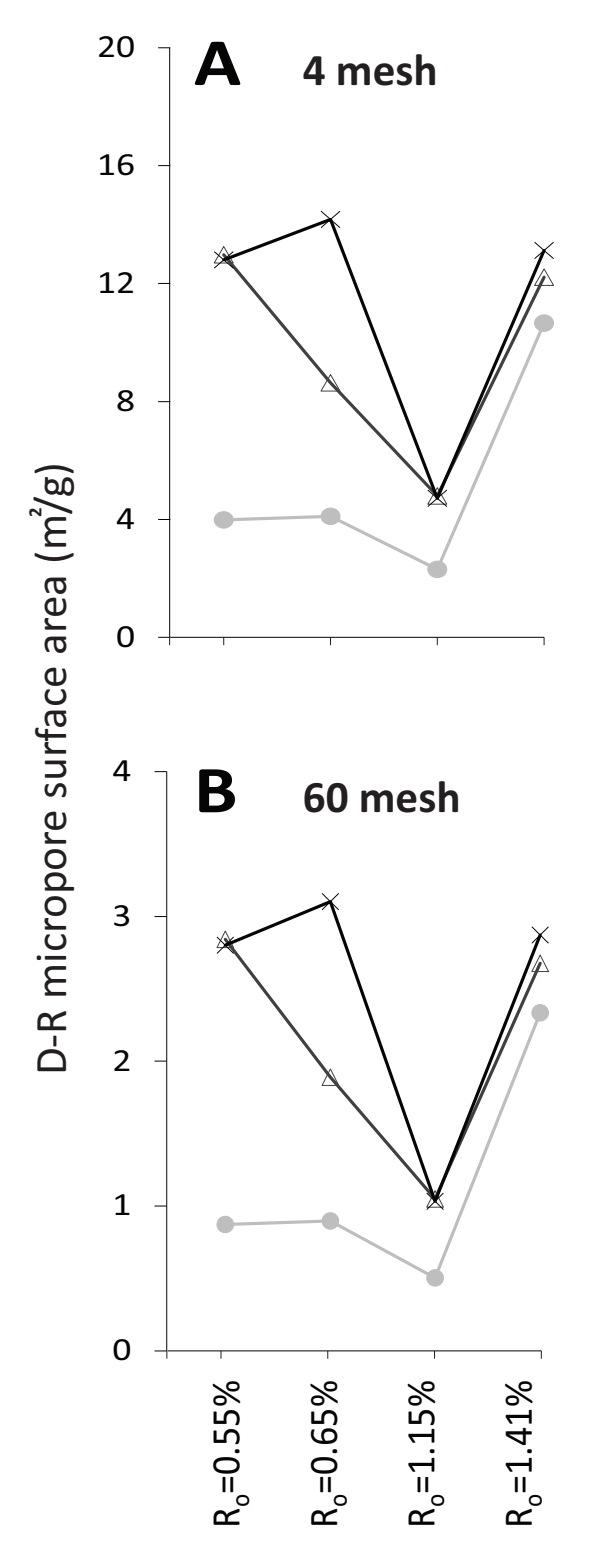

MM4 NA2 IL-5 IL-1

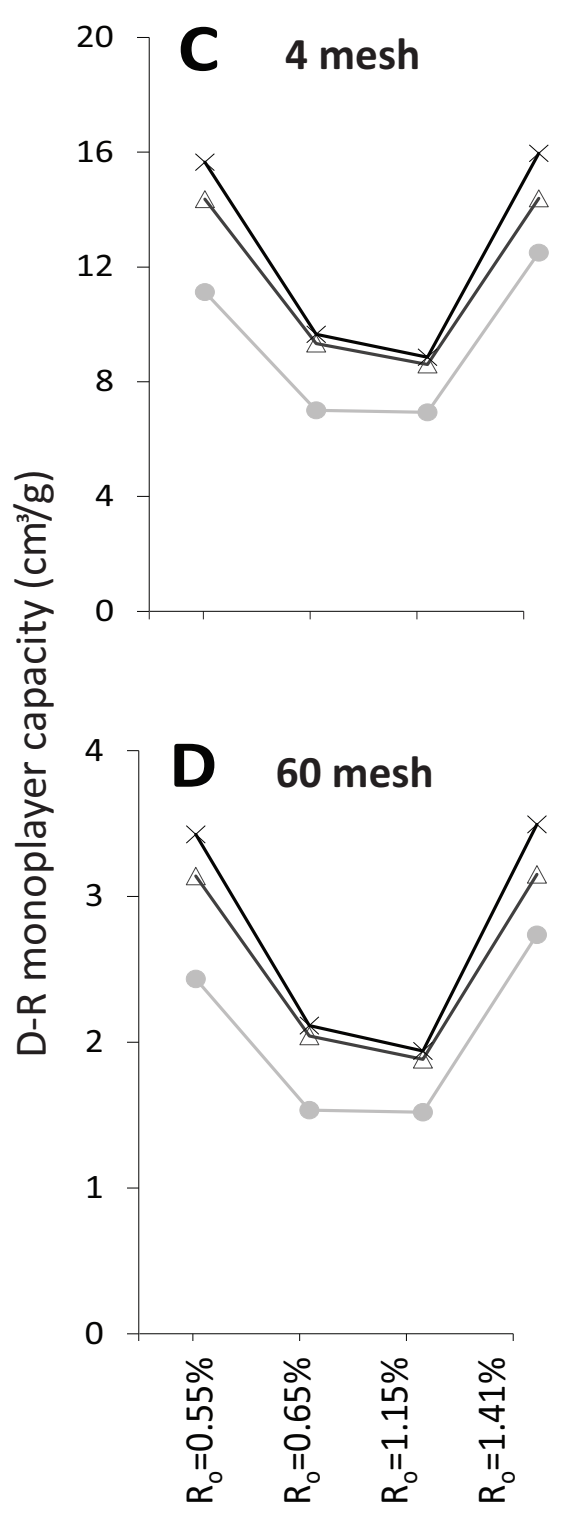

MM4 NA2 IL-5 IL-1

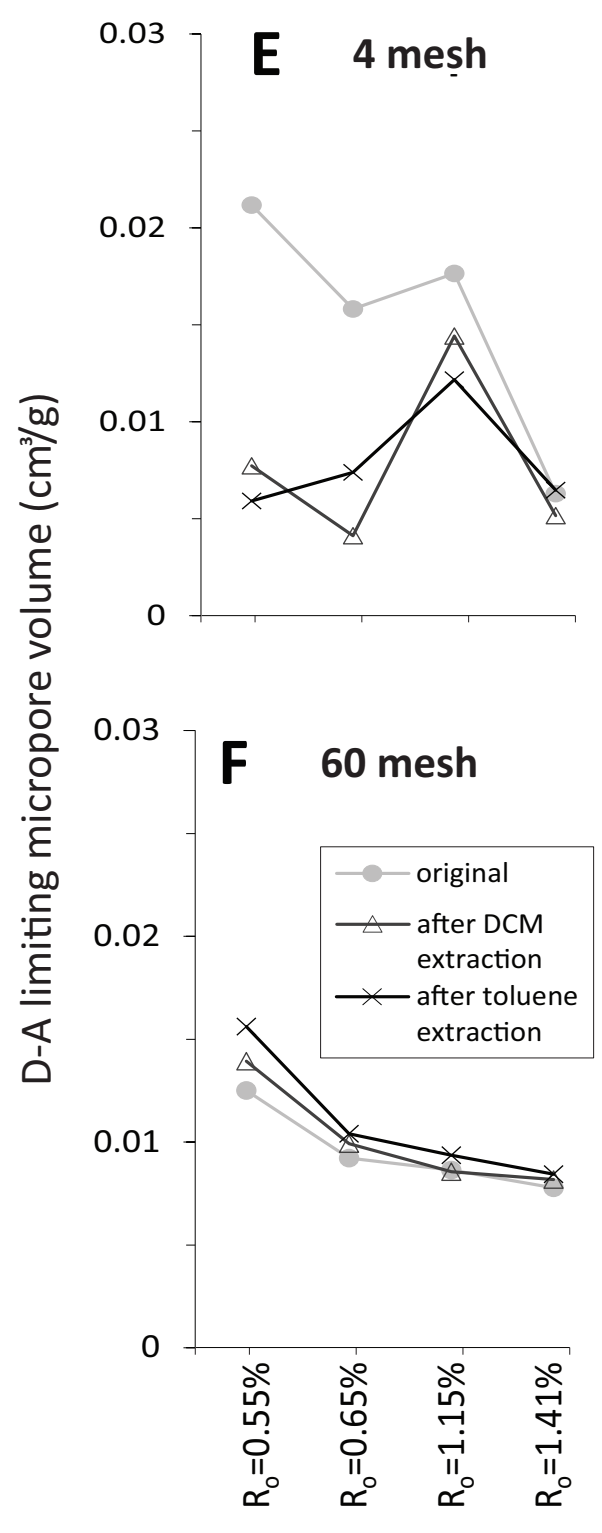

MM4 NA2 IL-5 IL-1 

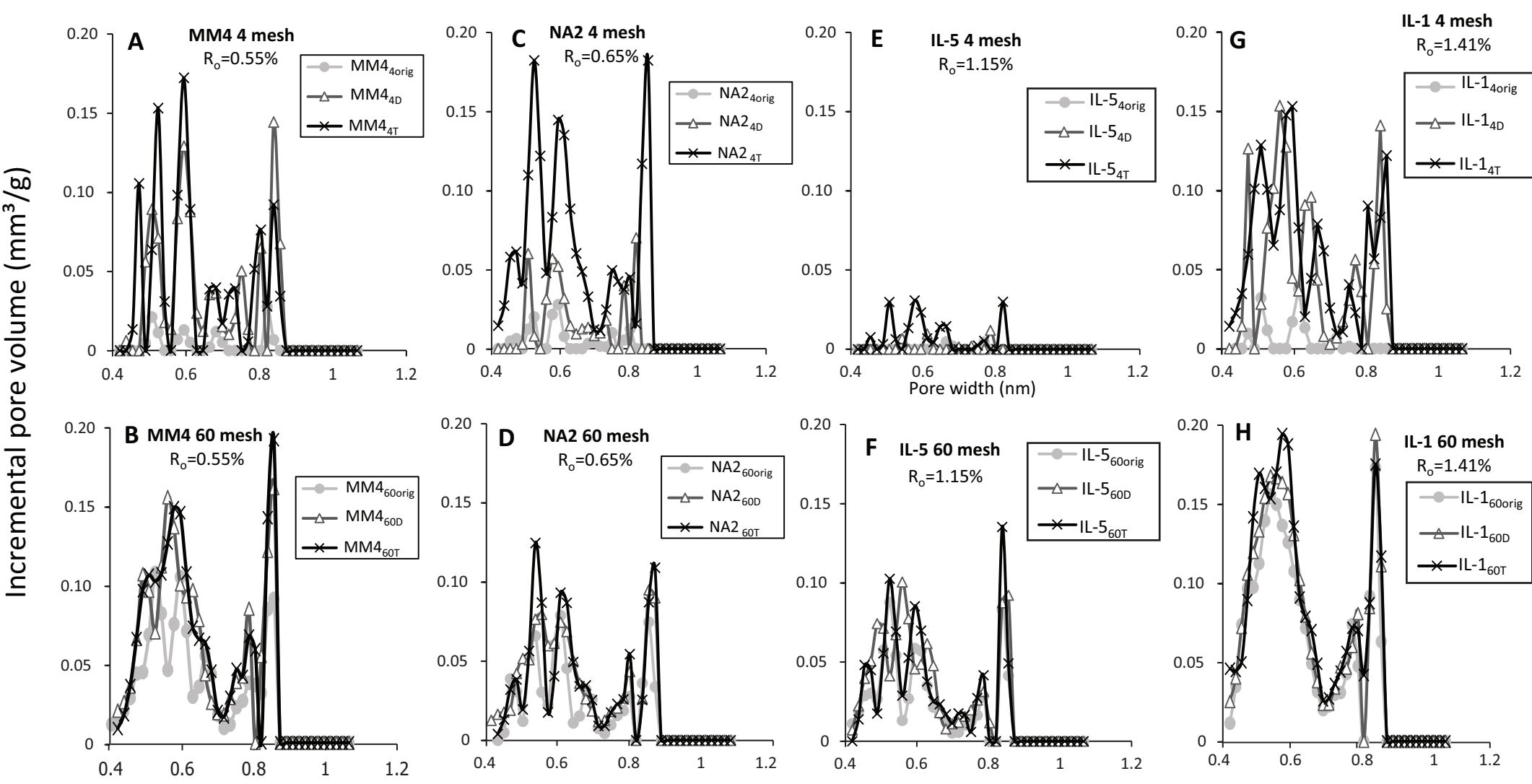

Pore width (nm) 


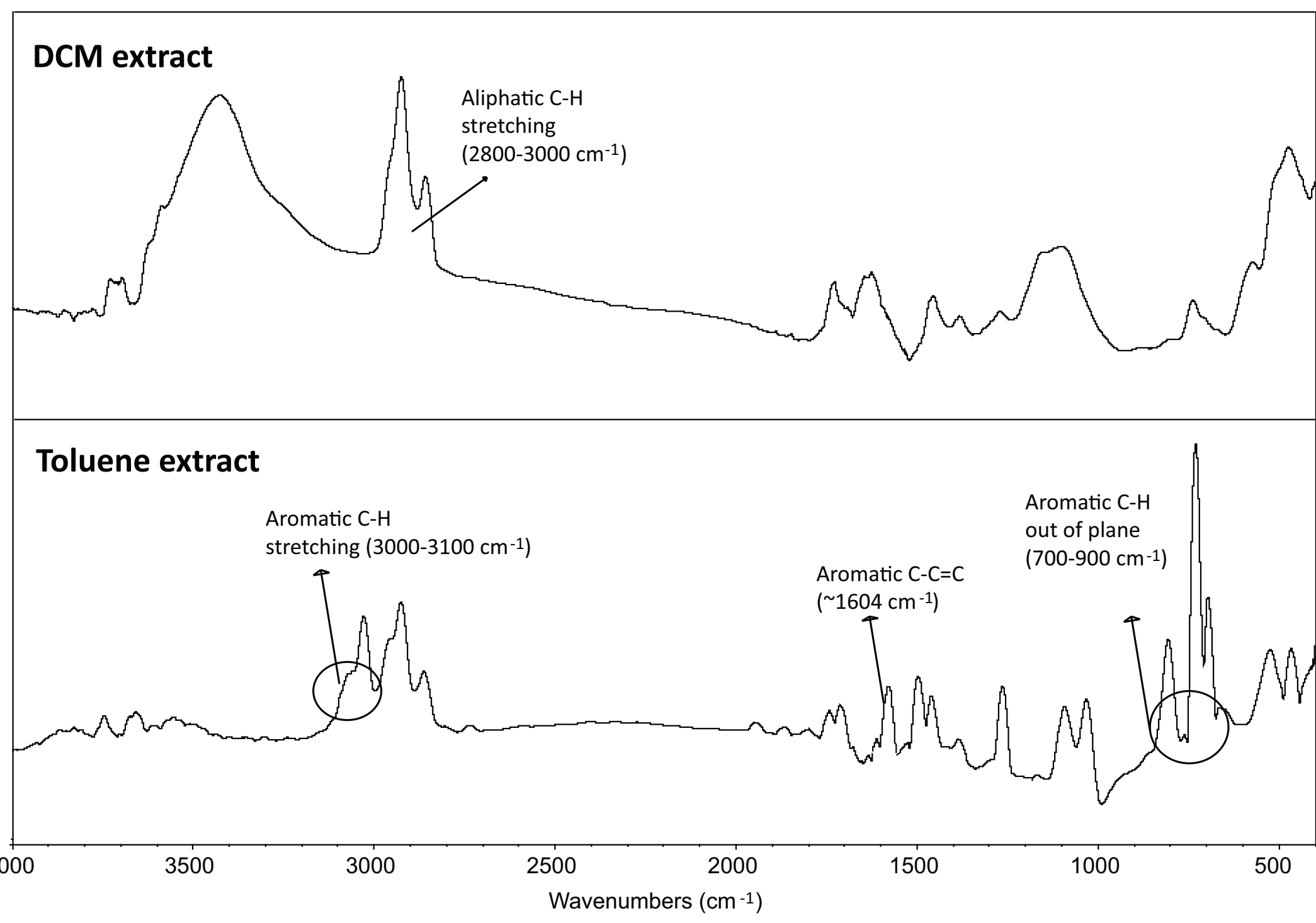


Table 1. Vitrinite reflectance $\left(R_{0}\right)$, total organic carbon (TOC) content, maturity, bitumen content, and total porosity by helium porosimetry of shale samples. The bitumen content was determined by maceral analysis (volume \%, on mineral matter free basis, mmf) (modified from Mastalerz et al., 2013).

\begin{tabular}{ccccccc} 
Sample & $\mathrm{R}_{\mathrm{o}}(\%)$ & TOC (wt. \%) & Depth $(\mathrm{m})$ & Maturity stage & $\begin{array}{c}\text { Bitumen content } \\
\text { (vol. \%, mmf) }\end{array}$ & $\begin{array}{c}\text { Helium porosimetry } \\
\text { (total pore volume } \mathrm{cm}^{3} / \mathrm{g} \text { ) }\end{array}$ \\
\hline MM4 & 0.55 & 13.0 & 764 & marginally mature & 2 & 0.0186 \\
NA2 & 0.65 & 5.3 & 853 & early mature & 10 & 0.0210 \\
IL-5 & 1.15 & 4.3 & 1607 & late mature & 45 & 0.0059 \\
IL-1 & 1.41 & 6.4 & 78 & post mature & 75 & 0.0141
\end{tabular}

Table 2. Changes in pore parameters (in \%) after sequential extractions of original shales with dichloromethane (DCM) and toluene. For example, Soxhlet extraction of the original shale sample MM4 with DCM resulted in a $20 \%$ increase in the mesopore BET surface area. All changes are relative to the original, unextracted shales.

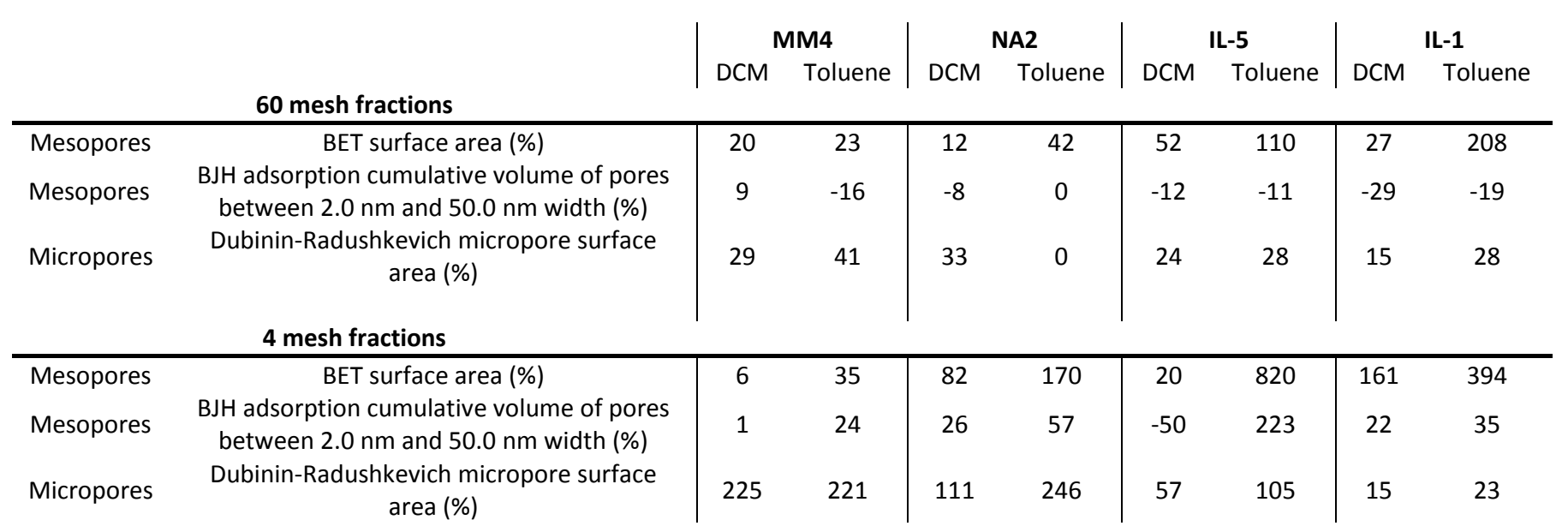


Table 3. Helium porosimetry, dry weights, and dry extract weight percentages as a consequence of sequential DCM and toluene Soxhlet extractions.

Helium porosimetry $\left(\mathrm{cm}^{3} / \mathrm{g}\right)$

Original weight of rock $(\mathrm{g})$

Dry DCM extract (g)

Dry DCM extract (wt. \% of original rock)

Dry weight of rock after DCM extraction $(\mathrm{g})$

Dry toluene extract $(\mathrm{g})$

Dry toluene extract (wt. \% of original rock)

Original weight of rock $(\mathrm{g})$

Dry DCM extracted (g)

Dry DCM extracted (wt. \% of original rock)

Dry weight of rock after DCM extraction (g)

Dry weight of rock after toluene extraction (g)

Dry toluene extraction (wt. \% of original rock)

\begin{tabular}{cccc} 
MM4 & NA2 & IL-5 & IL-1 \\
\hline 0.019 & 0.021 & 0.006 & 0.014 \\
\cline { 4 - 4 } 2.041 & 2.094 & 2.121 & 2.106 \\
0.020 & 0.021 & 0.017 & 0.036 \\
0.98 & 1.00 & 0.79 & 1.59 \\
2.019 & 2.073 & 2.104 & 2.073 \\
0.021 & 0.022 & 0.027 & 0.034 \\
1.03 & 1.05 & 1.27 & 1.61 \\
\hline 1.974 & 1.815 & 1.832 & 1.804 \\
0.024 & 0.026 & 0.032 & 0.037 \\
1.22 & 1.44 & 1.73 & 2.02 \\
1.949 & 1.789 & 1.801 & 1.768 \\
0.025 & 0.030 & 0.036 & 0.039 \\
1.26 & 1.65 & 1.97 & 2.16
\end{tabular}


Table 4. Average mesopore size distribution before and after sequential DCM and toluene extractions of 60-mesh fractions.

\begin{tabular}{|c|c|c|c|c|c|c|}
\hline \multirow[b]{2}{*}{$\begin{array}{l}\text { Average pore width } \\
\qquad(\mathrm{nm})\end{array}$} & original & $\begin{array}{l}\text { after DCM } \\
\text { extraction }\end{array}$ & $\begin{array}{c}\text { after toluene } \\
\text { extraction }\end{array}$ & original & $\begin{array}{l}\text { after DCM } \\
\text { extraction }\end{array}$ & $\begin{array}{c}\text { after toluene } \\
\text { extraction }\end{array}$ \\
\hline & 14.28 & 13.67 & 11.56 & 15.12 & 12.68 & 12.99 \\
\hline \multirow[b]{2}{*}{$\begin{array}{l}\text { Average pore width } \\
\qquad(\mathrm{nm})\end{array}$} & original & $\begin{array}{l}\text { after DCM } \\
\text { extraction }\end{array}$ & $\begin{array}{c}\text { after toluene } \\
\text { extraction }\end{array}$ & original & $\begin{array}{l}\text { after DCM } \\
\text { extraction } \\
\end{array}$ & $\begin{array}{c}\text { after toluene } \\
\text { extraction }\end{array}$ \\
\hline & 13.25 & 8.38 & 9.89 & 13.12 & 12.57 & 9.81 \\
\hline
\end{tabular}


Table 5. BET surface areas $\left(\mathrm{m}^{2} / \mathrm{g}\right)$ after sequential DCM and toluene extractions of 60 -mesh fractions.

\begin{tabular}{|c|c|c|c|c|}
\hline & $\begin{array}{c}\mathrm{MM4} \\
\mathrm{R}_{\mathrm{o}} \mathbf{0 . 5 5 \%}\end{array}$ & $\begin{array}{c}\text { NA2 } \\
R_{0} \mathbf{0 . 6 5 \%}\end{array}$ & $\begin{array}{c}\text { IL-5 } \\
R_{0} 1.15 \%\end{array}$ & $\begin{array}{c}\text { IL-1 } \\
R_{o} 1.41 \%\end{array}$ \\
\hline $\begin{array}{c}\text { Original BET surface } \\
\text { area }\end{array}$ & 4.45 & 4.10 & 4.11 & 3.06 \\
\hline $\begin{array}{l}\text { BET surface area } \\
\left(\mathrm{m}^{2} / \mathrm{g}\right) \text { after DCM } \\
\text { extraction }\end{array}$ & 5.36 & 4.61 & 6.25 & 3.90 \\
\hline $\begin{array}{c}\text { BET surface area } \\
\left(\mathrm{m}^{2} / \mathrm{g}\right) \text { after toluene } \\
\text { extraction }\end{array}$ & 5.48 & 5.82 & 8.65 & 9.42 \\
\hline $\begin{array}{l}\text { Increase of the BET } \\
\text { surface area }\left(\mathrm{m}^{2} / \mathrm{g}\right) \\
\text { caused by toluene } \\
\text { extraction }\end{array}$ & 0.12 & 1.21 & 2.40 & 5.52 \\
\hline
\end{tabular}

